\title{
Towards the optimization of botanical insecticides research: Aedes aegypti larvicidal natural products in French Guiana
}

Falkowski Michaël 1, Jahn-Oyac Arnaud 1, Odonne Guillaume 2, Flora Claudiane 1, Estevez Yannick 1 , Touré Seindé ${ }^{1,3}$, Boulogne Isabelle ${ }^{1,4,5}$, Robinson Jean-Charles ${ }^{6}$, Béreau Didier ${ }^{6}$, Petit Philippe ${ }^{4}$, Azam Didier ${ }^{7}$, Coke Maïra ${ }^{7}$, Issaly Jean ${ }^{8}$, Gaborit Pascal ${ }^{8}$, Stien Didier ${ }^{9}$, Eparvier Véronique ${ }^{3}$,

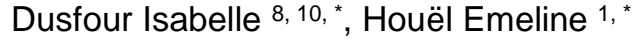

${ }^{1}$ CNRS, UMR EcoFoG, AgroParisTech, Cirad, INRA, Université des Antilles, Université de Guyane, 97300 Cayenne, France

2 Laboratoire Ecologie, Evolution, Interactions des Systèmes Amazoniens (LEEISA), CNRS, Université de Guyane, IFREMER, 97300 Cayenne, France

${ }^{3}$ CNRS, Institut de Chimie des Substances Naturelles, UPR2301, Université Paris Saclay, 91198 Gifsur-Yvette, France

${ }^{4}$ Université des Antilles, Campus de Fouillole, 97157 Pointe-à-Pitre Cedex, Guadeloupe, France

5 Université de ROUEN, UFR des Sciences et Techniques, Laboratoire Glycobiologie et Matrice Extracellulaire Végétale, UPRES-EA 4358, Fédération de Recherche « Normandie Végétal » FED 4277, 76821, Mont-Saint-Aignan, France.

6 Université de Guyane, Laboratoire COVAPAM, UMR QualiSud, Campus universitaire de Troubiran, BP 792, 97337 Cayenne cedex, France

7 Unité Expérimentale d'Ecologie et d'Ecotoxicologie Aquatique, INRA-U3E, 35042 Rennes, France

8 Institut Pasteur de la Guyane, Vectopôle Amazonien Emile Abonnenc, Unité Contrôle et Adaptation des vecteurs, 23 avenue Pasteur, BP6010, 97306 Cayenne cedex, France

${ }_{9}^{9}$ Sorbonne Université, CNRS, Laboratoire de Biodiversité et Biotechnologie Microbienne, LBBM, Observatoire Océanologique, 66650 Banyuls-sur-mer, France

10 INRS-Institut Armand Frappier, Groupe recherche en écologie microbienne, 531 boulevard des prairies, H7V 1B7, Laval, QC, Canada

* Corresponding authors : Isabelle Dusfour, email address : isabelle.dusfour@pasteur.fr ; Emeline Houël, email address : emeline.houel@ecofog.gf

\begin{abstract}
:
Natural products have proven to be an immeasurable source of bioactive compounds. The exceptional biodiversity encountered in Amazonia, alongside a rich entomofauna and frequent interactions with various herbivores is the crucible of a promising chemodiversity. This prompted us to search for novel botanical insecticides in French Guiana. As this French overseas department faces severe issues linked to insects, notably the strong incidence of vector-borne infectious diseases, we decided to focus our research on products able to control the mosquito Aedes aegypti. We tested 452 extracts obtained from 85 species originating from 36 botanical families and collected in contrasted environments against an Aedes aegypti laboratory strain susceptible to all insecticides, and a natural population resistant to both pyrethroid and organophosphate insecticides collected in Cayenne for the most active of them. 8 species (Maytenus oblongata Reissek, Celastraceae; Costus erythrothyrsus Loes., Costaceae; Humiria balsamifera Aubl., Humiriaceae; Sextonia rubra (Mez) van der Werff, Lauraceae; Piper hispidum Sw.,
\end{abstract}


Piperaceae; Laetia procera (Poepp.) Eichl., Salicaceae; Matayba arborescens (Aubl.) Radlk., Sapindaceae; and Cupania scrobitulata Rich., Sapindaceae) led to extracts exhibiting more than $50 \%$ larval mortality after $48 \mathrm{~h}$ of exposition at $100 \mu \mathrm{g} / \mathrm{mL}$ against the natural population and were considered active. Selectivity and phytochemistry of these extracts were therefore investigated and discussed, and some active compounds highlighted. Multivariate analysis highlighted that solvents, plant tissues, plant family and location had a significant effect on mortality while light, available resources and vegetation type did not. Through this case study we highlighted that plant defensive chemistry mechanisms are crucial while searching for novel insecticidal products.

\section{Graphical abstract}

French Guiana biodiversity was explored for the search of novel larvicidal products against both insecticide-susceptible and -resistant Aedes aegypti populations.

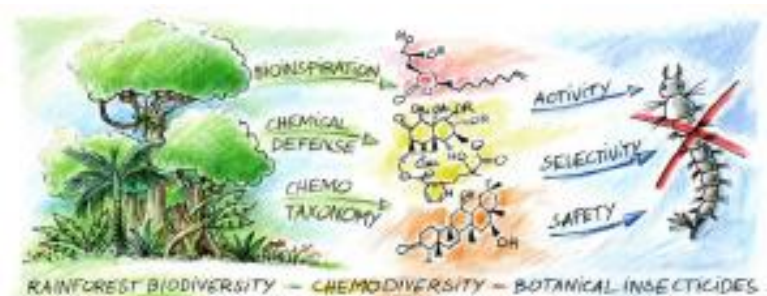

\section{Highlights}

- French Guiana biodiversity was explored for the search of novel botanical insecticidal products 452 extracts from 85 plant species were tested for larvicidal activity against Aedes aegypti Bioassays included both insecticide-susceptible and -resistant Ae. aegypti populations Sextonia rubra wood extract and its main components were highlighted as promising products Correlations between extracts larvicidal activity and plants chemical defense were investigated

Keywords : Mosquito larvicides ; Culicidae ; Amazonian chemodiversity ; screening optimization ; quasiPoisson generalized linear model ; chemical defense 


\section{Introduction}

Although botanical insecticides are at the origin of all insecticidal compounds, they have been laid or put aside by the agrochemical industry. However due to the great damages caused by the overuse of synthetic compounds, natural products and molecules obtained from plants are again considered suitable pest control alternatives (George et al. 2014; Gerwick and Sparks 2014; Isman 2015). The considerable needs, efforts, challenges and limitations of this research are in particular described in a recent review, also presenting a wide range of plant extracts tested for larvicidal activity against various mosquitoes (Pavela et al., 2019).

Intensification of research on natural insecticides is in particular due to the crucial need of effective products to control mosquito vectors of pathogens, particularly viruses and Plasmodium parasites (Benelli 2015; Benelli and Mehlhorn 2016). Indeed during last years, the world has regularly experienced the emergence or re-emergence of arthropod-borne viruses such as yellow fever, dengue, chikungunya, and more recently Zika viruses. As 
vector control remains an important, if not the sole tool to fight diseases spread, this increasing number of outbreaks alongside the expansion of insecticide resistance urge the development of novel molecules to control invasive mosquito populations such as Aedes aegypti (L., 1762) and Aedes albopictus (Skuse, 1895) (Carvalho and Moreira 2017; Fauci and Morens 2016; Faucon et al. 2015; Higgs and Vanlandingham 2015; Moyes et al. 2017). In particular Ae. aegypti Linnaeus (Diptera: Culicidae) is a cosmopolitan species originating from Africa but now well-established in all tropical and subtropical regions. This mostly diurnal anthropophilic mosquito is foud in urban communities and surrounding area, its presence being favoured by the existence of artificial breeding sites such as used tires, water tanks or flower pots. Its opportunistic behavior, high adaptation ability and biological characteristic such as eggs resistant to dessication, alongside with trade globalization and rapid urbanization are some keys of this species' ecological success (Carvalho and Moreira 2017; Simmons et al., 2012; Abilio et al., 2018). As sessile organisms, plants must have developed a wide range of secondary metabolites as defense compounds against predators and pests during their evolution (Agrawal and Weber 2015; Fraenkel 1959). The exceptional biodiversity of plants, entomofauna and herbivores in the tropics leads to a promising chemodiversity, due to the constant and dynamic interactions between plants and their environment (Becerra 2007; Ehrlich and Raven 1964; Richards et al.2015). Some factors were highlighted for playing a major role in the effectiveness of defense. According to the optimal defense theory, the allocation of defense chemicals is driven by the predation pressure exercised on a given plant organ, and the fitness value of this organ for the plant (McCall and Fordyce 2010; McKey 1974). Besides, not only this fitness value but also resources from a given environment would drive both the type and the amount of secondary metabolites (Coley et al. 1985; Endara and Coley, 2011). Open environments also represent places of higher herbivorous insects' abundance, and therefore larger insects-plants interactions, which could lead to the production of more, and/or more diverse insecticidal compounds (Lamarre et al. 2012). The type of defense may also differ between plants. Longliving, slow-growing species including woody plants would allocate resources to highly 
concentrated quantitative defenses such as polyphenols and tannins, while short-lived species, e.g. herbaceous plants, would synthetize smaller amount of low molecular weight toxic compounds such as alkaloids, phenolic compounds or cyanogenic glycosides (Feeny 1976; Rhoades and Cates 1976; Smilanich et al. 2016).

For a few years, our team has therefore built a collection of plant extracts from ecologically contrasted Amazonian environments, including long-lasting trees and herbaceous plants, extracted from different plant organs. The objective was to consider plants having various growth-defense trade-offs in order to potentially improve our capacity to discover insecticidal compounds, and investigate ecological trends governing insecticidal properties. This approach has been inspired by the concept of "human chemical defenses" presented by Berenbaum (Berenbaum 1995). Literature-based chemotaxonomy was also included as a criterion for plant selection in our search for novel larvicidal extracts and compounds. As a consequence of the project, some methodological issues had to be discussed considering the huge amount of scientific literature already dealing with botanical insecticides research (Isman and Grieneisen 2014). The present contribution therefore also addresses some of these issues through illustrative examples encountered along the study, in an attempt to optimize plant screening for natural insecticides discovery.

\section{Materials and methods}

\subsection{Plant material}

All plant species (Table 1) were collected in French Guiana. They are not protected species and their collection was allowed without restriction at the concerned locations. Collection authorizations were given by the ONF (National Forest Office) where necessary. Herbarium vouchers were deposited in French Guiana Herbarium (CAY) where specialists confirmed botanical identification. All collection data are available at: http://publish.plantnetproject.org/project/caypub. 


\begin{tabular}{|c|c|c|c|c|}
\hline Botanical families & Plant species & CAY & Location $^{\mathrm{a}}$ & Plant part \\
\hline \multirow[t]{4}{*}{ Annonaceae } & Anaxagorea dolichocarpa Sprague \& Sandwith & Odonne 721 & Ko & Leaves, stems \\
\hline & Guatteria ouregou (Aubl.) Dunal & Odonne 718 & Ko & Leaves, stems \\
\hline & Xylopia cayennensis Maas & Odonne 788 & $\mathrm{Ma}$ & Leaves, bark \\
\hline & Xylopia frutescens var. ferruginea R.E. Fr. & Odonne 774 & $\mathrm{Ma}$ & Leaves, stems, bark \\
\hline \multirow[t]{2}{*}{ Apocynaceae } & Tabernaemontana siphilitica (L.f.) Leeuwenb. & Odonne 724 & Ko & Aerial parts \\
\hline & Lacmellea aculeata (Ducke) Monach. & Odonne 749 & $\mathrm{Si}$ & Leaves, stems \\
\hline Asteraceae & Bidens cynapiifolia Kunth & Odonne 760 & Mc & Whole plant \\
\hline \multirow[t]{2}{*}{ Bignoniaceae } & Handroanthus capitatus (Bureau \& K. Schum.) & Odonne 795 & $\mathrm{Rg}$ & Leaves, stems \\
\hline & Adenocalymma moringifolium (DC.) L. & Odonne 727 & Ko & Aerial parts \\
\hline Boraginaceae & Varronia schomburgkii (DC.) Borhidi & Odonne 789 & $\mathrm{Ma}$ & Aerial parts \\
\hline \multirow[t]{2}{*}{ Celastraceae } & Maytenus oblongata Reissek & Odonne 726 & Ko & Leaves, stems \\
\hline & Maytenus sp. & Odonne 797 & $\mathrm{Rg}$ & Leaves and fruits, stems \\
\hline \multirow[t]{2}{*}{ Chrysobalanaceae } & Couepia bracteosa Benth. & Odonne 775 & $\mathrm{Ma}$ & Leaves, stems \\
\hline & Licania affinis Fritsch & Odonne 716 & Ko & Leaves, stems \\
\hline Clusiaceae & Clusia palmicida Rich. & Odonne 798 & $\mathrm{Rg}$ & Leaves, stems \\
\hline Combretaceae & Terminalia amazonia (J.F. Gmel.) Exell & Odonne 783 & $\mathrm{Ma}$ & Leaves, bark \\
\hline Convolvulaceae & Ipomoea leprieurii D.F. Austin & Odonne 791 & $\mathrm{Rg}$ & Aerial parts \\
\hline \multirow[t]{4}{*}{ Costaceae } & Costus erythrothyrsus Loes. & Odonne 742 & $\mathrm{Si}$ & Leaves, stems, inflorescence \\
\hline & Costus cf spiralis (Jacq.) Roscoe & Houël 3 & $\mathrm{Rm}$ & Inflorescence \\
\hline & Costus spiralis var. villosus Maas & Houël 4 & Ko & Inflorescence \\
\hline & Costus spiralis var. villosus Maas & Houël 5 & Ro & Inflorescence \\
\hline Cyperaceae & Scleria cyperina Willd. ex Kunth & Odonne 793 & $\mathrm{Rg}$ & Aerial parts \\
\hline
\end{tabular}




\begin{tabular}{|c|c|c|c|c|}
\hline Dilleniaceae & Tetracera asperula Miq. & Odonne 781 & $\mathrm{Ma}$ & Leaves, fruits \\
\hline \multirow[t]{8}{*}{ Euphorbiaceae } & Cnidoscolus urens (L.) Arthur & Odonne 790 & Mc & Aerial parts \\
\hline & Conceveiba guianensis Aubl. & Odonne 722 & Ko & Leaves, stems \\
\hline & Croton guianensis Aubl. & Odonne 786 & 1a & Leaves \\
\hline & Croton macradenis Görts \& Punt & Eparvier 202 & Mo & Aerial parts \\
\hline & Croton matourensis Aubl. & Eparvier 167 & Mt & Leaves, bark \\
\hline & Croton nuntians Croizat & Eparvier 199 & $\mathrm{Si}$ & Leaves, stems \\
\hline & Croton nuntians Croizat & Odonne 743 & $\mathrm{Si}$ & Leaves, stems \\
\hline & Sapium argutum (Müll. Arg.) Huber & Odonne 794 & $\mathrm{Rg}$ & Leaves, stems \\
\hline \multirow[t]{15}{*}{ Fabaceae } & Alexa wachenheimii Benoist & Odonne 719 & Ko & Leaves, bark \\
\hline & Bocoa prouacensis Aubl. & $238^{b}$ & $\mathrm{Si}$ & Bark \\
\hline & Chamaecrista desvauxii var. s & Odonne 806 & $\mathrm{Rg}$ & Aerial parts \\
\hline & Irwin \& Barneby & & & \\
\hline & Chamaecrista diphylla (L.) Greene & Odonne 758 & $\mathrm{Mc}$ & Aerial parts \\
\hline & Dalbergia monetaria L.f. & Odonne 762 & Mc & Leaves, stems \\
\hline & Desmodium barbatum (L.) Benth. & Odonne 746 & $\mathrm{Si}$ & Whole plant \\
\hline & Dimorphandra polyandra Benoist & Odonne 779 & $\mathrm{Ma}$ & Leaves, bark \\
\hline & Entada polystachya (L.) DC. & Odonne 759 & $\mathrm{Mc}$ & Leaves, stems \\
\hline & Enterolobium schomburgkii (Benth.) Benth. & Forget 4976 & $\mathrm{Si}$ & Wood, bark \\
\hline & Inga alba (Sw.) Willd. & Moretti 1129 & $\mathrm{Si}$ & Wood \\
\hline & Inga virgultosa (Vahi) Desv. & Odonne 805 & $\mathrm{Rg}$ & Leaves, stems \\
\hline & Muellera frutescens (Aubl.) Standl. & Eparvier 108B & Mo & Leaves \\
\hline & Macrolobium bifolium (Aubl.) Pers. & Odonne 725 & Ko & Leaves, stems \\
\hline & Macrolobium guianense (Aubl.) Pulle & Odonne 785 & $\mathrm{Ma}$ & Leaves, wood \\
\hline
\end{tabular}




\begin{tabular}{|c|c|c|c|c|}
\hline & Ormosia coutinhoi Ducke & Odonne 717 & Ko & Leaves, stems \\
\hline & Senna quinquangulata (Rich.) H.S. Irwin \& Barneby & Odonne 738 & $\mathrm{Si}$ & Leaves, stems \\
\hline & Spirotropis longifolia (DC.) Baill. & Eparvier 137 & $\mathrm{Si}$ & Wood, bark, roots \\
\hline & Stylosanthes guianensis (Aubl.) Sw. & Odonne 792 & $\mathrm{Rg}$ & Aerial parts \\
\hline & Swartzia guianensis (Aubl.) Urb. & Odonne 715 & Ko & Leaves, stems \\
\hline & Vigna luteola (Jacq.) Benth. & Odonne 764 & Mc & Aerial parts \\
\hline \multirow[t]{2}{*}{ Humiriaceae } & Humiria balsamifera Aubl. & Eparvier 101 & Mc & Wood \\
\hline & Humiria balsamifera Aubl. & Odonne 784 & Ma & Bark \\
\hline \multirow[t]{3}{*}{ Lauraceae } & Licaria cannella (Meisn.) Kosterm. & Silland 16 & $\mathrm{Rg}$ & Wood \\
\hline & Sextonia rubra (Mez) van der Werff & $1039^{\mathrm{b}}$ & $\mathrm{Si}$ & Bark \\
\hline & Sextonia rubra (Mez) van der Werff & Rodrigues 12 & $\mathrm{Rg}$ & Wood \\
\hline Loranthaceae & Phthirusa sp. & Odonne 720 & Ko & Leaves, stems \\
\hline Lythraceae & Cuphea blackii Lourteig & Odonne 796 & $\mathrm{Rg}$ & Aerial parts \\
\hline \multirow[t]{3}{*}{ Malpighiaceae } & Byrsonima aerugo Sagot & Odonne 780 & $\mathrm{Ma}$ & Leaves \\
\hline & Byrsonima crassifolia (L.) Kunth & Odonne 755 & Mc & Leaves, bark \\
\hline & Byrsonima spicata (Cav.) DC. & Odonne 754 & Mc & Leaves, wood, bark \\
\hline \multirow[t]{2}{*}{ Malvaceae } & Eriotheca surinamensis (Uittien) A. Robyns & Odonne 801 & $\mathrm{Rg}$ & Leaves \\
\hline & Sterculia pruriens (Aubl.) K. Schum & $1058^{b}$ & $\mathrm{Si}$ & Bark \\
\hline Melastomataceae & Ernestia granvillei Wurdack & Odonne 804 & $\mathrm{Rg}$ & Aerial parts \\
\hline \multirow[t]{2}{*}{ Meliaceae } & Azadirachta indica A. Juss & Odonne 712 & Ko & Leaves \\
\hline & Guarea guidonia (L.) Sleumer & Odonne 756 & Mc & Leaves, stems \\
\hline Moraceae & Bagassa guianensis Aubl. & n.i. ${ }^{c}$ & $\mathrm{Si}$ & Bark \\
\hline Myrtaceae & Myrcia saxatilis (Amshoff) McVaugh & Odonne 799 & $\mathrm{Rg}$ & Leaves, stems \\
\hline Orobanchaceae & Anisantherina hispidula (Mart.) Pennell & Odonne 757 & Mc & Whole plant \\
\hline
\end{tabular}




\begin{tabular}{|c|c|c|c|c|}
\hline Piperaceae & Piper hispidum Sw. & Odonne 741 & $\mathrm{Si}$ & Leaves, stems \\
\hline Polygalaceae & Polygala longicaulis Kunth & Odonne 787 & $\mathrm{Ma}$ & Whole plant \\
\hline \multirow[t]{3}{*}{ Rubiaceae } & Posoqueria longiflora Aubl. & Odonne 723 & Ko & Leaves \\
\hline & Tocoyena guianensis K. Schum. & Odonne 802 & $2 g$ & Aerial parts \\
\hline & Sipanea pratensis Aubl. & Odonne 803 & $\mathrm{Rg}$ & Aerial parts \\
\hline \multirow[t]{5}{*}{ Salicaceae } & Banara guianensis Aubl. & Odonne 748 & $\mathrm{Si}$ & Leaves, stems \\
\hline & Casearia grandiflora Cambess. & Odonne 777 & $\mathrm{Ma}$ & Leaves, wood, bark \\
\hline & Laetia procera (Poepp.) Eichl. & 10 & $\mathrm{Si}$ & Bark \\
\hline & Laetia procera (Poepp.) Eichl. & $424^{b}$ & $\mathrm{Si}$ & Bark \\
\hline & Laetia procera (Poepp.) Eichl. & Odonne 771 & Mc & Bark \\
\hline \multirow[t]{4}{*}{ Sapindaceae } & Cupania scrobiculata Rich. & Odonne 778 & $\mathrm{Ma}$ & Leaves, stems, fruits \\
\hline & Matayba arborescens (Aubl.) Radlk. & Odonne 776 & $\mathrm{Ma}$ & Leaves, stems, fruits \\
\hline & Paullinia sp. & Odonne 713 & $\mathrm{Si}$ & Leaves, stems \\
\hline & Paullinia pinnata $\mathrm{L}$. & Odonne 763 & Mc & Aerial parts \\
\hline Sapotaceae & Manilkara huberi (Ducke) A. Chevalier & Riéra 1904 & $\mathrm{Si}$ & Wood, bark \\
\hline Simaroubaceae & Quassia amara L.. & Odonne 714 & $\mathrm{Rm}$ & Stems \\
\hline Siparunaceae & Siparuna guianensis Aubl. & Odonne 747 & $\mathrm{Si}$ & Leaves, stems \\
\hline \multirow[t]{4}{*}{ Solanaceae } & Cestrum latifolium Lam. & Odonne 761 & Mc & Leaves, stems \\
\hline & Solanum leucocarpon Dunal & Odonne 740 & $\mathrm{Si}$ & Leaves, stems \\
\hline & Solanum stramoniifolium Jacq. & Odonne 751 & $\mathrm{Si}$ & Aerial parts \\
\hline & Solanum subinerme Jacq. & Odonne 752 & $\mathrm{Si}$ & Aerial parts \\
\hline Vochysiaceae & Erisma uncinatum Warm. & $514^{\mathrm{b}}$ & $\mathrm{Si}$ & Bark \\
\hline
\end{tabular}


a Legend: Régina (Rg), Roura (Ro), Matoury (Mt), Rémire-Montjoly (Rm), Montsinéry-Tonnegrande (Mo), Macouria (Mc), Kourou (Ko), Sinnamary (Si), Mana (Ma)

b Trees from a permanent plot (St Elie) in Sinnamary. This permanent research plot hosts up to 800 identified trees. The systematic identification of the trees was performed at the IRD herbarium in Cayenne where a voucher sample is deposited

${ }^{c}$ Not integrated in Cayenne herbarium. Bagassa guianensis was collected in the framework of other research projects and botanical identification was made in situ by professional forest workers

Table 1 Botanical families, plant species, voucher number (Cayenne herbarium - CAY), location and plant parts collected for testing against $3^{\text {rd }}$ $4^{\text {th }}$ instar larvae of Ae. aegypti L. (Diptera: Culicidae) 
Plants were collected along an E/W geographical gradient (Figure 1) in the following locations: Régina (Rg), Roura (Ro), Matoury (Mt), Rémire-Montjoly (Rm), MontsinéryTonnegrande (Mo), Macouria (Mc), Kourou (Ko), Sinnamary (Si), Mana (Mn). The various environment types were the following: terra firme forest, forest edges, white-sand forest, river bank, dry savannah, coastline, inselberg and ruderal/disturbed areas. To perform multivariate analysis, these environments were described according to the available light (few light: forest, to strong light: open environment such as savannah or inselberg) and resources (from poor environment such as inselbergs to abundant resources environment such as forest or river bank) at the collection place. The type of vegetation (life-forms) was also characterized (temporary vegetation, secondary / low or slightly ligneous vegetation, ligneous species, large trees). Collected plant organs were: bark, wood, stems, roots, leaves, aerial parts, whole plant, inflorescence and fruits depending on the plant.

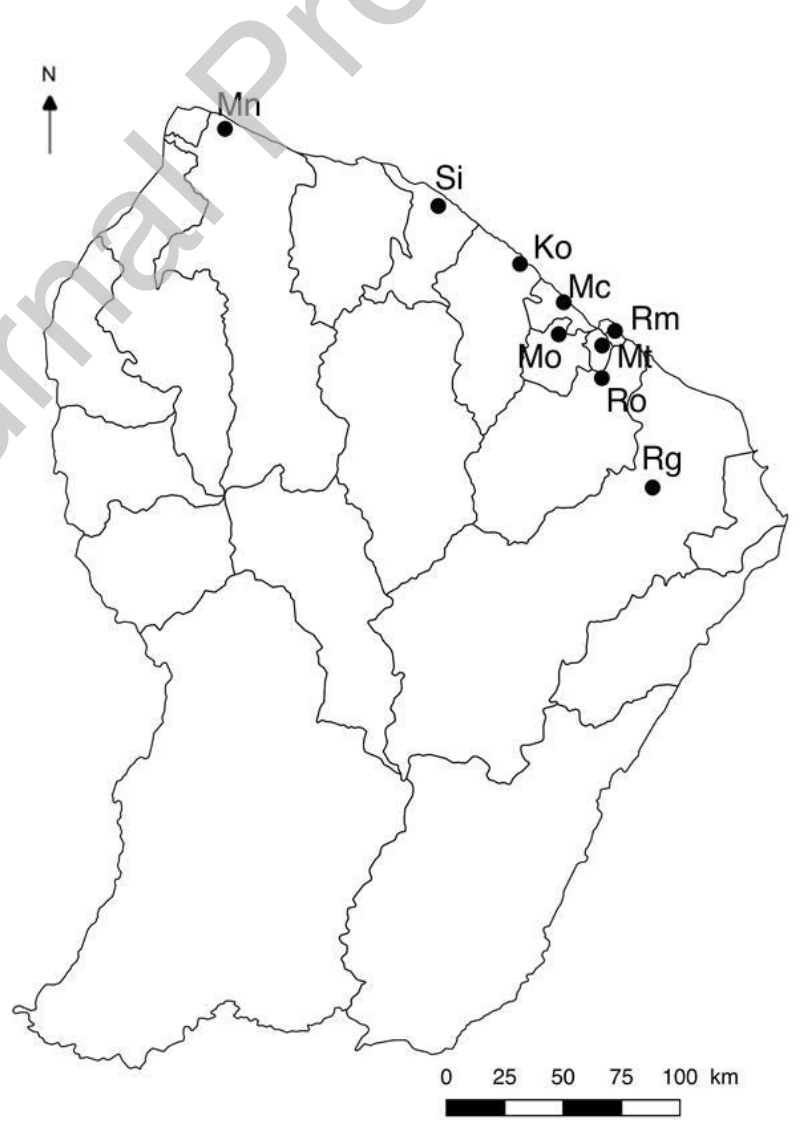


Fig. 1 Repartition of the collection localities. Legend: Régina (Rg), Roura (Ro), Matoury (Mt), Rémire-Montjoly (Rm), Montsinéry-Tonnegrande (Mo), Macouria (Mc), Kourou (Ko), Sinnamary (Si), Mana (Ma)

\subsection{Extraction}

All plant parts were air-dried (room temperature, 10\% air relative humidity) and finely ground into powder prior to extraction. Plant powders $(30 \mathrm{~g})$ were successively extracted at room temperature by maceration during $24 \mathrm{~h}$ under stirring, using either ethyl acetate $(3 \times 150 \mathrm{ml})$ followed by methanol $(1 \times 150 \mathrm{ml})$, or petroleum ether $(3 \times 150 \mathrm{ml})$ followed by boiling water $(1 \times 150 \mathrm{ml})$. After each extraction, the solution was filtered and the solvent removed by evaporation under reduced pressure with a SpeedVac ${ }^{\mathrm{TM}}$ concentrator (Savant SPD121P, Thermo Scientific). The resulting crude extracts (up to 4 extracts for each plant part of each species) were stored in a freezer at $-18^{\circ} \mathrm{C}$ until assayed.

\subsection{Evaluation of larvicidal activity}

Insect collection and rearing, cup assay and data analysis were performed as previously described (Touré et al. 2017). Two Aedes aegypti (Diptera: Culicidae) strains were used for testing the extracts and compounds. The laboratory strain Paea, collected in French Polynesia, and maintained for a decade in the insectary at the Institut Pasteur de la Guyane, French Guiana, is susceptible to all insecticides. The Cayenne natural population is resistant to both pyrethroid and organophosphate insecticides and is a first generation (F1) strain reared from wild-caught larvae (F0) (Dusfour et al. 2011). The choice to perform a two-step screening was based on the recommendations made by Cos et al. for antimicrobial screening to develop a stronger proof of concept (Cos et al. 2006). Indeed LC $\mathrm{C}_{50}$ could increase 100 times in Ae. aegypti resistant populations compared to susceptible ones (Lima et al. 2011). Late third or early fourth-instar larvae were used in the tests. All extracts were 
investigated using the WHO procedure for testing of mosquito larvicides (WHO 2005). For each bioassay, 25 larvae of each strain were transferred to cups containing $99 \mathrm{~mL}$ of distilled water and $1 \mathrm{~mL}$ of the tested product diluted in ethanol, at the suitable concentration, and four cups, representing a total of 100 larvae, were used for each tested concentration. For the determination of mortality rates, the final concentration was $100 \mu \mathrm{g} / \mathrm{mL}$ and for $\mathrm{LC}_{50}$ calculation, concentrations leading from 0 to $100 \%$ mortality were tested. Larval mortality was recorded 24 and $48 \mathrm{~h}$ after exposure. Control treatments were performed for each test with $1 \mathrm{~mL}$ of ethanol, and deltamethrin $(0.05 \mu \mathrm{g} / \mathrm{mL})$ was used as a positive control in the case of the laboratory strain Paea. Muellera frutescens (Aubl.) Standl. (Fabaceae), of which leaves were previously described to contain the rotenoid compounds rotenone, tephrosin and deguelin, and to be toxic against Ae. aegypti mosquito larvae, was included in the screening to serve as a botanical positive control in order to validate the test protocol (Falkowski et al. 2016; Nirma et al. 2009). Abbott's formula was applied to mortalities if mortality in the control was between $5 \%$ and $20 \%$ (Abbott 1925). The test was invalidated if mortality in the control was greater than $20 \%$. Lethal doses were obtained by a probit regression under a general linearized model [BioRssay 6.1. script in R environment version 3.2.0 (https://www.rproject.org/)].

\subsection{Cytotoxicity assays}

Cytotoxicity assays were conducted with KB (nasopharyngeal epidermoid carcinoma) and MRC5 (normal lung tissue of a 14-week-old male foetus) cell lines using the procedure described by Tempête et al. (Tempête et al. 1995). Docetaxel was used as positive control.

\subsection{Ecotoxicological assessment on non-target species, Daphnia magna and} Chironomus riparius 
Ecotoxicity assays were adapted from the guidelines of the "Immediate Immobilization Test" (OECD No. 202) for Daphnia magna (Straus, 1820) and the "Immediate Immobilization Test" (OECD No. 235) for Chironomus riparius (Meigen, 1804). The extracts were tested only at the $\mathrm{LC}_{50}$ value defined from the Ae. aegypti Paea strain sensitivity for each extract. Three conditions were tested: control, control/solvent, and $\mathrm{LC}_{50}$, with four replicates per condition. The physicochemical measurements ( $\mathrm{pH}$, dissolved oxygen, conductivity) were performed with measuring devices (sensors). The remaining measures (chlorine, nitrites, nitrates, phosphates) were performed with aquarium strips. Photoperiod and temperature were recorded using a "templight" recorder throughout the test period, from clutch incubation until the end of the exposure.

\subsection{Phytochemical studies}

\subsubsection{General remarks}

${ }^{1} \mathrm{H}$ NMR spectra were recorded at $400 \mathrm{MHz}$ and ${ }^{13} \mathrm{C}$ NMR spectra at $100.6 \mathrm{MHz}$ on a Varian $400 \mathrm{MR}$ spectrometer equipped with a $5 \mathrm{~mm}$ inverse probe (Auto X PGF 1H/15N-13C). Samples were dissolved in deuterated chloroform $\left(\mathrm{CDCl}_{3}\right)$ in $5 \mathrm{~mm}$ tubes as stated. Chemical shifts are in ppm downfield from tetramethylsilane (TMS), and coupling constants ( $\mathcal{J}$ ) are in $\mathrm{Hz}$ (s stands for singlet, $\mathrm{d}$ for doublet, $\mathrm{t}$ for triplet, $\mathrm{q}$ for quartet, $\mathrm{m}$ for merduplet, br for broad). TLC analyses were performed using ALUGRAM®SIL G/UV 254 plates, eluted with petroleum ether 90:10 and revealed using a solution of $1 \% \mathrm{KMnO}_{4}$ in water.

Water (HPLC grade) was obtained from a Milli-Q system (Milli-Q plus, Millipore Bedford, MA). HPLC analyses were performed on a Discovery C18 column $(15 \mathrm{~cm} \times 4.6 \mathrm{~mm}, 5 \mu \mathrm{m}$, Supelco) at $1 \mathrm{~mL} / \mathrm{min}$ using a Waters HPLC system equipped with a W2996 photodiode array absorbance detector and a W2424 light-scattering detector. HPLC semi-preparative chromatography was performed at $15 \mathrm{~mL} / \mathrm{min}$ on a Discovery C18 column (15 cm x 21.2 $\mathrm{mm}, 5 \mu \mathrm{m}$, Supelco) using a Waters HPLC system equipped with a W600 pump and a W2487 double wavelength UV detector (Waters). 


\subsubsection{Costus erythrothyrsus Loes. (Costaceae) phytochemical study}

C. erythrothyrsus inflorescence ethyl acetate extract was purified by column chromatography using a petroleum ether / ethyl acetate gradient from 100:0 to $10: 90$ and eventually $100 \%$ methanol. Ten fractions were gathered according to their TLC profile. Fraction F4 eluted with petroleum ether / ethyl acetate 85:15 exhibited 72\% larvicidal mortality against Ae. aegypti Paea laboratory strain at $100 \mu \mathrm{g} / \mathrm{mL}$ and $100 \%$ larvicidal mortality against Cayenne resistant strain at the same concentration, and its chemical composition was therefore investigated using NMR. TLC profiles from the crude extract and fraction F4 were also compared to standard lipids L13-0521 (VHOSO, Very High Oleic Sunflower Oil fatty acids), L13-0001 (Linseed oil fatty acids including 50\% linolenic acid $21 \%$ linoleic acid and $13 \%$ oleic acid), E12-1986 (stearic acid), L14-0146 (hydrogenated VHOSO methylic ester - stearic acid) and P14-002 (VHOSO methylic ester - oleic acid) kindly provided by ITERG (Institut des Corps Gras, Pessac, France).

\subsubsection{Maytenus oblongata Reissek (Celastraceae) phytochemical study}

The thoroughgoing bioguided fractionation as well as isolation and identification of $M$. oblongata extract components were described in Touré et al. (2017).

\subsubsection{Sextonia rubra (Mez.) van der Werff (Lauraceae) phytochemical study}

Isolation of rubrenolide and rubrynolide was performed using HPLC semi-preparative chromatography according to previously described procedures (Fu et al. 2019) and their identification confirmed by NMR. 


\subsection{Multivariate analysis}

The complete set of data used for multivariate analysis is available in Supporting Information (table S1). Multivariate analysis was conducted in R 3.2.0 environment. Z-scores were obtained from mortality data. This transformation gives the dataset a mean of 0 and a standard deviation of 1. A generalized linear model (GLM) using the quasi-Poisson distribution, logistic link function and a mixture of forwards and backwards selection was used to relate mortality responses to the technical, chemotaxonomic and environmental predictor variables. Pairwise comparisons were further performed with TukeyHSD test between modalities of each factor that were identified to have an effect on mortalities. Family, solvent, organ, light, resource, type of vegetation and location were thus selected as explanatory variables in our analyses.

\section{Results and discussion}

\subsection{Larvicidal screening on susceptible and resistant Ae. aegypti strains}

A total of 144 plant parts issued from 85 species belonging to 36 botanical families were collected during the project (Table 1). Fabaceae (24\%) were the most represented, with 17 genera and 20 species. Euphorbiaceae, Annonaceae, Sapindaceae and Solanaceae represented from 5 to $8 \%$ of the collected species (Figure 2). The genera Byrsonima, Croton and Solanum were the most represented, with 3 to 4 species each. For two species (Croton nuntians Croizat, Euphorbiaceae, Laetia procera (Poepp.) Eichler, Salicaceae) 2 to 3 different samples of the same plant part were collected at different times and locations. It should be noticed that the Fabaceae family is one of the most cited in the literature for its insecticidal activity, being notably a source of rotenoids and in particular rotenone, a wellknown, yet controversial botanical insecticide (Boulogne et al. 2012; Isman 2006; Pavela et al., 2019). 


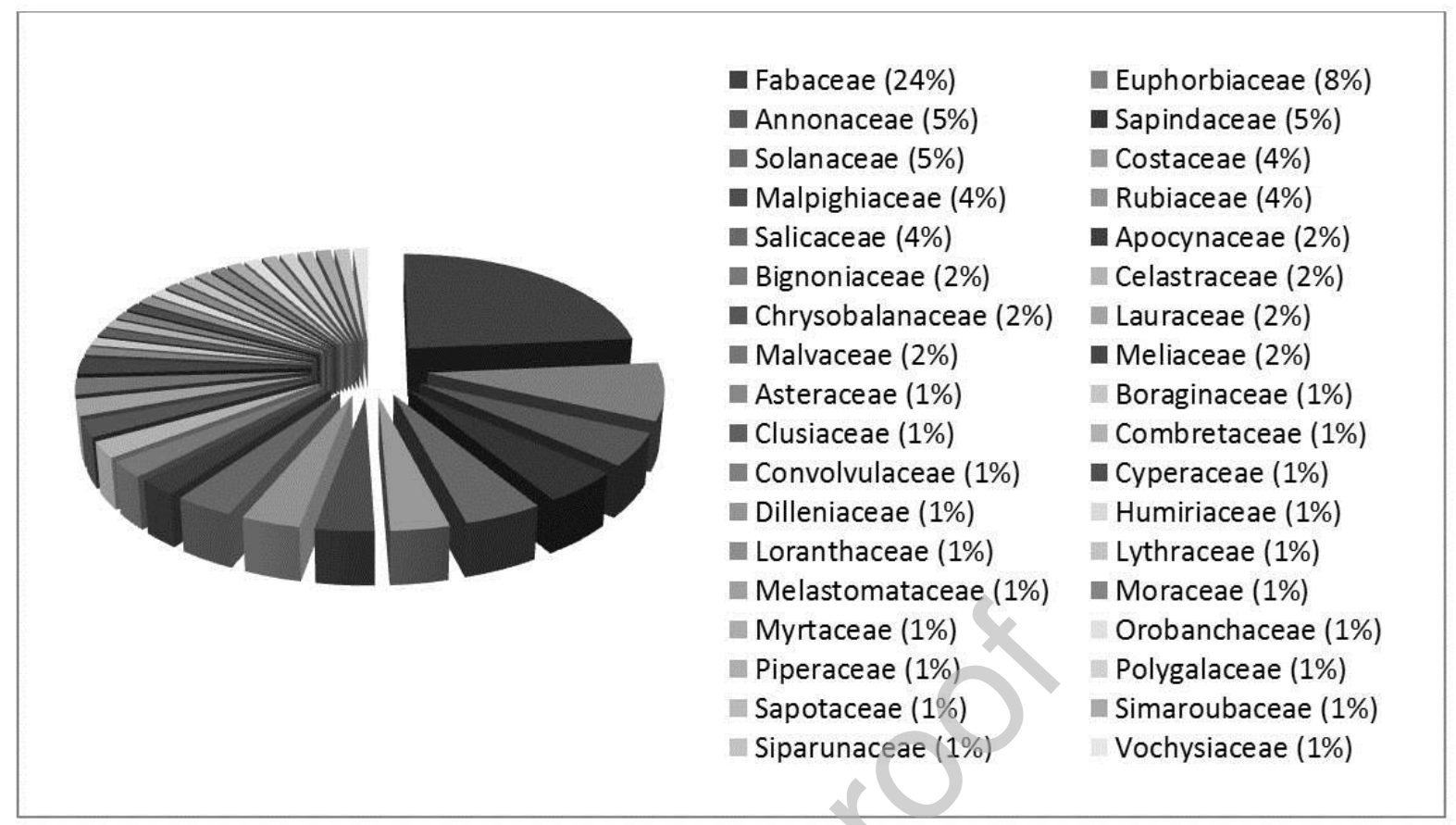

Fig. 2 Diversity of the collected species: the relative importance of the botanical families is shown in the pie chart (families are represented clockwise in the pie chart)

Eventually, 452 extracts were obtained and tested on Ae. aegypti Paea strain. The complete dataset is available in Supporting Information (Table S1). The extracts exhibiting more than $50 \%$ mortality after $48 \mathrm{~h}$ of exposition at $100 \mu \mathrm{g} / \mathrm{mL}$ were considered active, which is consistent with the requirements proposed by Pavela (2015). Fifteen botanical species thus led to 22 larvicidal extracts listed in Table 2. The active extracts on the Paea strain were then tested on a natural population of resistant Cayenne Ae. aegypti in order to obtain more selective and realistic results, thus improving the probability to highlight promising plant extracts for the search of new botanical insecticides.

The extracts exhibiting larvicidal mortality $\geq 50 \%$ after $48 \mathrm{~h}$ of exposition at $100 \mu \mathrm{g} / \mathrm{mL}$ against this resistant strain are highlighted in Table 2. Eventually, 8 species led to 11 larvicidal extracts against the Cayenne strain. Among the botanical families hosting these active species Celastraceae (Alvarenga and Ferro 2005; Deepa and Narmatha Bai 2010), 
Lauraceae (Cuca-Suarez et al. 2012; Dias and Moraes, 2014), Piperaceae (Dorla et al. 2017; Lija-Escaline and al. 2015; Marques and Kaplan 2015), and Sapindaceae (Diaz and Rossini 2012), are particularly well described for their numerous insecticidal effects. These 8 species represents $9 \%$ of the collected species and $2 \%$ of the extracts. By comparison, among 94 extracts from 10 Brazilian plant species selected randomly or according to chemotaxonomic criteria, 19 were considered to be effective against $A e$. aegypti larvae, exhibiting $L_{50}<250$ $\mu \mathrm{g} / \mathrm{mL}$, including 6 (6.4\%) extracts with $\mathrm{LC}_{50}<100 \mu \mathrm{g} / \mathrm{mL}$ (Oliveira et al. 2010). Another 27 species identified from a screening performed on 83 Asteraceae belonging to 48 genera, promoted statistically significant mortality of Ae. fluviatilis (Lutz, 1904) $4^{\text {th }}$ instar larvae, with 8 (9.6\%) species leading to $50 \%$ or more mortality at $100 \mu \mathrm{g} / \mathrm{mL}$ (Macêdo et al. 1997). In terms of active extracts, these results are consistent with those observed in our screening, even if contrary to the example of the Asteraceae family, the selected plants in our case did not all belong to botanical families well-known for the insecticidal activities of their species. This could be an indication that selecting species on different criteria, e.g. the ecosystem, could also lead to interesting results. 


\begin{tabular}{|c|c|c|c|c|c|c|c|c|}
\hline Botanical families & Plant species $^{a}$ & Plant part & Solvent $^{c}$ & $\begin{array}{l}\text { Extraction } \\
\text { yield }(\%)\end{array}$ & $\begin{array}{c}\text { Mortality (\%, } \\
\text { Paea strain) } \\
\pm \text { SD }\end{array}$ & $\mathrm{LC}_{50}(\mu \mathrm{g} / \mathrm{ml})$, Paea strain ${ }^{d}$ & $\begin{array}{l}\text { Mortality (\%, } \\
\text { Cayenne } \\
\text { strain) } \\
\pm \text { SD }^{\mathrm{e}}\end{array}$ & $\begin{array}{c}\mathrm{LC}_{50}(\mu \mathrm{g} / \mathrm{ml}), \text { Cayenne } \\
\text { strain }^{\mathrm{d}}\end{array}$ \\
\hline Annonaceae & Xylopia frutescens var. ferruginea & Leaves & $\mathrm{PE}$ & 3.0 & $54 \pm \overline{6.6}$ & & $4 \pm 0.0$ & \\
\hline Asteraceae & Bidens cynapiifolia & Whole plant & EA & 1.4 & $97 \pm 1.0$ & & $5 \pm 3.0$ & \\
\hline Celastracee & Maytenus oblongata & Stems & EA & 1.5 & $98 \pm 1.1$ & $74.4 \pm 2.5^{\prime}$ & $91 \pm 3.0$ & n.t. \\
\hline \multirow{2}{*}{ Chrysobalanaceae } & Licania affinis & Leaves & PE & 0.8 & $97 \pm 1.1$ & & $2 \pm 1.1$ & \\
\hline & Licania affinis & Stems & $\mathrm{PE}$ & 0.1 & $100 \pm 0.0$ & & n.t. & \\
\hline \multirow[t]{2}{*}{ Costaceae } & Costus erythrothyrsus (Odonne 742) & Inflorescence & EA & 4.8 & $100 \pm 0.0$ & 45.0 (95\%Cl: 36.6-54.0) & $100 \pm 0.0$ & 55.7 (95\%Cl: 49.8-61.2) \\
\hline & Costus erythrothyrsus (Odonne 742) & Inflorescence & PE & 3.9 & $97 \pm 1.0$ & n.t. & $99 \pm 1.0$ & n.t. \\
\hline Euphorbiaceae & Croton macradenis & Aerial parts & PE & 0.4 & $54 \pm 3.8$ & & $5 \pm 1.9$ & \\
\hline \multirow[t]{4}{*}{ Fabaceae } & Alexa wachenheimii & Bark & $\mathrm{PE}$ & 0.2 & $56 \pm 2.8$ & & $2 \pm 1.1$ & \\
\hline & Muellera frutescens ${ }^{D}$ & Leaves & PE & 3.7 & $100 \pm 0.0$ & & n.t. & \\
\hline & Muellera frutescens & Leaves & EA & 4.3 & $100 \pm 0.0$ & & n.t. & \\
\hline & Muellera frutescens & Leaves & M & 4.6 & $97 \pm 1.9$ & & n.t. & \\
\hline Humiriaceae & Humiria balsamifera (Odonne 784) & Bark & EA & 17.9 & $84 \pm 4.3$ & $49.0(95 \% \mathrm{Cl} 35.8-64.8)$ & $91 \pm 1.9$ & $45.0(\mathrm{Cl} 95 \% 39.0-51.2)$ \\
\hline \multirow[t]{2}{*}{ Lauraceae } & Sextonia rubra (Rodrigues 12) & Wood & EA & 4.2 & $100.0 \pm 0.0$ & $3.17(95 \% \mathrm{Cl} 2.7-3.7)$ & $100.0 \pm 0.0$ & n.t. \\
\hline & Sextonia rubra (1039) & Bark & EA & 2.4 & $100.0 \pm 0.0$ & n.t. & $85.0 \pm 6.0$ & n.t. \\
\hline Piperaceae & Piper hispidum & Leaves & EA & 7.0 & $62 \pm 5.3$ & $54.7(95 \% \mathrm{Cl} 46.0-64.0)$ & $84 \pm 1.6$ & n.t. \\
\hline \multirow[t]{2}{*}{ Salicaceae } & Laetia procera (1003) & Bark & PE & 3.4 & $94 \pm 2.0$ & $33.5(95 \% \mathrm{Cl} 28.0-39.8)$ & $87 \pm 3.4$ & $61.0(95 \% \mathrm{Cl} 49.8-77.7)$ \\
\hline & Laetia procera (1003) & Bark & EA & 2.7 & $63 \pm 6.0$ & 43.7 (95\%Cl: 33.9-57.3) & $57 \pm 7.2$ & 65.9 (95\%Cl: 51.7-90.5) \\
\hline \multirow[t]{3}{*}{ Sapindaceae } & Matayba arborescens & Fruits & EA & 11.2 & $60 \pm 2.8$ & $76.9(95 \% \mathrm{Cl} 67.7-86.7)$ & $98 \pm 1.1$ & $40.5(95 \% \mathrm{Cl} 34.1-46.2)$ \\
\hline & Matayba arborescens & Fruits & PE & 17.4 & $51 \pm 6.6$ & n.t. & $50 \pm 6.8$ & n.t. \\
\hline & Cupania scrobiculata & Fruits & EA & 2.9 & $64 \pm 1.6$ & $105.3(95 \% \mathrm{Cl} 86.6-136.5)$ & $74 \pm 3.8$ & $102.5(95 \% \mathrm{Cl} 80.4-145.4)$ \\
\hline Solanaceae & Cestrum latifolium & Stems & EA & 0.7 & $58 \pm 10.5$ & & $7 \pm 1.9$ & \\
\hline
\end{tabular}


a Voucher number at Cayenne Herbarium (CAY) or tree number from a permanent plot in Sinnamary is indicated when several samples were previously collected

${ }^{\mathrm{b}}$ Muellera frutescens was used as a botanical insecticide positive control in order to validate the test protocol

${ }^{c} \mathrm{PE}$ : petroleum ether; EA: ethyl acetate; M: methanol

${ }^{d} \mathrm{LC}_{50}$ values were calculated after $48 \mathrm{~h}$ of exposition unless otherwise specified

e n.t.: not tested.

${ }^{\dagger} \mathrm{LC}_{50}$ value was calculated after $24 \mathrm{~h}$ of exposition using the protocol descred in Touré et al. (2017)

Table 2 Active extracts (mortality $\geq 50 \%$ after $48 \mathrm{~h}$ of exposition at $100 \mu \mathrm{g} / \mathrm{mL}$ ) against $A e$. aegypti Paea and Cayenne strains $3^{\text {rd }}-4^{\text {th }}$ instar larvae. Extracts exhibiting larvicidal activities $\geq 50 \%$ against Cayenne resistant strain are highlighted in bold characters. 


\subsection{Selectivity of the active extracts and phytochemical discussion}

In the global perspective of improving our knowledge about the selectivity of the extract in terms of bioactivity, cytotoxicity of the extracts highlighted as active on the Ae. aegypti Cayenne strain was then evaluated on two human cellular strains (KB cancerous cell line, MRC5 healthy cell line). Concurrently 3 randomly selected extracts (Maytenus oblongata Reissek, Celastraceae, Matayba arborescens (Aubl.) Radlk., Sapindaceae, and Humiria balsamifera Aubl., Humiriaceae) were tested for possible ecotoxicity against non-target species $C$. riparius, an aquatic diptera, and $D$. magna, a small planktonic crustacean. If the obtained values (inhibition of cellular growth for cytotoxic assay, and mortality for ecotoxicity) were too high, the extract was abandoned. These bioassays were used at this step of the screening to prevent further study of active non-selective extracts. Indeed, as stated by Isman and Grieneisen, studying the effect of botanical insecticides on human health is quite rare in the existing literature, as most botanicals are renowned for their low acute toxicity (Isman and Grieneisen 2014). However, plants can be highly toxic too and this parameter should clearly be taken into account in the context of the search for new insecticides of plant origin. The cytotoxicity results are presented in Table 3. Cupania scrobitulata Rich. (Sapindaceae) fruits extract was cytotoxic and was dropped. M. arborescens fruits extract was only moderately cytotoxic but was strongly ecotoxic with almost $100 \%$ of mortality against both $C$. riparius and $D$. magna at $100 \mu \mathrm{g} / \mathrm{mL}$ and was therefore dropped as well.

H. balsamifera bark ethyl acetate extract exhibited significant cyto- and ecotoxicity, with respectively $52 \pm 2 \%$ and $40 \pm 5 \%$ of growth inhibition against KB and MRC5 cells at $10 \mu \mathrm{g} / \mathrm{ml}$, and leading to almost $100 \%$ of mortality against both $C$. riparius and $D$. magna at $80 \mu \mathrm{g} / \mathrm{mL}$. The latter value is close to the $\mathrm{LC}_{50}$ values of 63.6 (CI95\% 52.7-77.5) and 49.0 (CI95\% 35.864.8) $\mu \mathrm{g} / \mathrm{mL}$ measured at 24 and $48 \mathrm{~h}$ against the laboratory strain Paea. $H$. balsamifera is a large tree common in Amazonia and North-East Brazil. Numerous compounds were isolated from this species, including trans-isolongifolenone (Da Silva et al. 2004). ${ }^{48}$ Interestingly, a 
repulsive effect of this compound was described on Ae. aegypti and Anopheles stephensi, but also on other insects (Wang et al. 2013; Zhang et al. 2009). Moreover, transisolongifolenone is described as odorless, whereas some of its derivatives have a characteristic woody smell (Zhang et al. 2009). It has to be noted that the sampled bark was strongly odoriferous, and we noticed in the field that this phenomenon was linked to a damage caused to the bark, leading to an abundant production of resinous product. It should therefore be checked if the more frequently encountered non-odoriferous barks also lead to larvicidal extracts, and if odoriferous isolongifolenone derivatives exhibit larvicidal activity. In the case of this extract, toxicity could be linked with the plant's response to stress due to mechanical damage, leading to the production of defensive compounds. If these molecules led to the discovery of a larvicidal extract, our results also highlight the fact that cyto- and ecotoxicity bioassays are essential in the evaluation of a potential new insecticidal product, as $H$. balsamifera bark extract showed to be non-selective against the various targets tested in our study. It should also be mentioned that $H$. balsamifera wood extract did not exhibit any larvicidal activity in our hands. It would be interesting to investigate if this difference is linked to the collected specimen or to a systematic difference in terms of chemical defenses allocation between the two tissues. 


\begin{tabular}{|c|c|c|c|c|c|c|}
\hline \multirow[t]{2}{*}{ Botanical families } & \multirow[t]{2}{*}{ Plant species ${ }^{a}$} & \multirow{2}{*}{$\begin{array}{l}\text { Plant part / } \\
\text { Solvent }^{b}\end{array}$} & \multicolumn{2}{|c|}{$\begin{array}{c}\text { Growth inhibition of KB cells, } \\
\qquad \% \pm \text { SD }^{c}\end{array}$} & \multicolumn{2}{|c|}{$\begin{array}{l}\text { Growth inhibition of MRC5 cells, } \\
\qquad \% \pm \text { SD }^{c}\end{array}$} \\
\hline & & & $10 \mu \mathrm{g} / \mathrm{ml}$ & $1 \mu \mathrm{g} / \mathrm{mi}$ & $10 \mu \mathrm{g} / \mathrm{ml}$ & $1 \mu \mathrm{g} / \mathrm{ml}$ \\
\hline Celastracee & Maytenus oblongata & Stems (EA) & $9 \pm 1$ & n.t. & $8 \pm 6$ & n.t. \\
\hline Costaceae & Costus erythrothyrsus (Odonne 742) & Inflorescence (EA) & $0 \pm 1$ & $0 \pm 10$ & $0 \pm 1$ & $0 \pm 1$ \\
\hline Humiriaceae & Humiria balsamifera (Odonne 784) & Bark (EA) & $52 \pm 2$ & $5 \pm 2$ & $40 \pm 5$ & $18 \pm 4$ \\
\hline Piperaceae & Piper hispidum & Leaves (EA) & $22 \pm$ & $0 \pm 1$ & $0 \pm 4$ & $0 \pm 1$ \\
\hline Salicaceae & Laetia procera (1003) & Bark (PE) & $18 \pm 2$ & $0 \pm 1$ & $45 \pm 5$ & $4 \pm 1$ \\
\hline \multirow[t]{2}{*}{ Sapindaceae } & Matayba arborescens & Fruits (EA) & $24 \pm 6$ & n.t. & $16 \pm 2$ & n.t. \\
\hline & Cupania scrobiculata & Fruits (EA) & $71 \pm 1$ & $1 \pm 6$ & $67 \pm 2$ & $27 \pm 2$ \\
\hline
\end{tabular}

${ }^{a}$ Voucher number at Cayenne Herbarium (CAY) or tree number from a permanent plot in Sinnamary is indicated when several samples were previously collected

${ }^{b}$ PE: petroleum ether; EA: ethyl acetate; M: methanol

${ }^{c} \mathrm{PE}$ : petroleum ether; EA: ethyl acetate; M: methanol

Table 3 Growth inhibition of KB (nasopharyngeal epidermoid carcinoma) and MRC5 (normal lung tissue of a 14-week-old male fetus) cell lines.

Positive control: docetaxel induced $0.0005 \%$ survival at $1 \mu \mathrm{g} / \mathrm{mL}$. 
Species from the genus Costus are rhizomatous perennial herbs from the Costaceae family (Specht and Stevenson 2006). In our study, C. erythrothyrsus Loes. inflorescence ethyl acetate extract exhibited no cytotoxicity against human cell lines, which could make this extract a valuable candidate in the search of new botanical insecticides. The $\mathrm{LC}_{50}$ at 24 and $48 \mathrm{~h}$ were 69.1 (95\% Cl: 59.4-82.9) and 45.0 (95\% Cl: 36.6-54.0) $\mu \mathrm{g} / \mathrm{mL}$, respectively, against the Paea strain. Although the insecticidal activity of several Costus species has been described before in the literature, neither $C$. eryhthothyrsus nor Costus inflorescences were described for insecticidal activity (Pipithsangchan and Morallo-Rejesus 2005; Surendra Kumar et al. 2014). However, although the first extract exhibited strong larvicidal activity, no other positive result could be observed while testing inflorescences extracts from the same C. erythrothyrsus specimen at a later collection date, or inflorescences collected from other Costus species. Interestingly, we noticed that the first collected inflorescence had been damaged by some predators. Defense compounds may have been produced by the plant on this occasion, and further studies to investigate these mechanisms and the compounds responsible for the biological activity would thus be of great interest. In the case of this extract, bioguided fractionation allowed us to isolate an active mixture of 3 fatty acids. ${ }^{1} \mathrm{H}$ NMR spectrum was consistent with a mixture linolenic, linoleic and oleic acids (Figure S1) (Sacchi et al. 1997). This type of compounds were already found in a chemical analysis performed on the inflorescence of Etlingera elatior Jack, a plant from the Zingiberaceae family, which is in close relationship with Costaceae, and are known for their larvicidal activity (Harada et al. 2000; Jeevani Osadee Wijekoon et al. 2011; Rahuman et al. 2008; Ramsewak et al. 2001; Santos et al. 2017). Moreover, they were also highlighted for their role in chemical defense mechanisms, and more particularly induced defense against pathogenous organisms (Domingues et al. 2007; Rojas et al. 2014; Ryu et al. 2005). Therefore the fact that a single extract was found active might be correlated with the activation of defense mechanisms in response to herbivory damage and this observation could be the subject of complementary studies. 
The case of $L$. procera petroleum ether bark extract also raised interesting questions concerning the activation of chemical defense mechanisms and the interest of studying several samples of a same species. L. procera is a long-lived pioneer tree, i.e., a fastgrowing light-demanding species, characterized as an early colonizer of the Amazonian forest (Santos et al. 2012). Petroleum ether bark extract of L. procera $\mathrm{N}^{\circ} 1003$ collected in the Saint Elie permanent investigation plot in Sinnamary (Si) led to a LC $_{50}$ value of 33.5 (CI95\% 28.0-39.8) $\mu \mathrm{g} / \mathrm{mL}$ at $48 \mathrm{~h}$ against the laboratory strain Paea. However, no larvicidal activity was discovered while testing two other bark extracts. One inactive tree bark had been collected in the same mature forest area as the active bark (tree $\mathrm{N}^{\circ} 424$ ), and the second one in a secondary forest close to dry savannahs in Macouria (Mc). Therefore, the activity described for the first sample could be due again to an increased production of toxic compounds by a single individual rather than an environmental effect of resources availability. Indeed, Jullian et al. already described the fact that bark extracts from the same tree $\mathrm{N}^{\circ} 1003$, collected a few years before, led to the isolation of laetiaprocerine $\mathrm{A}$ and laetianolide $\mathrm{A}$ as major compounds, whereas casearlucine $\mathrm{A}$ and caseamembrol $\mathrm{A}$ were the main components of tree $\mathrm{N}^{\circ} 424$ bark extract, alongside with small amounts of laetiaprocerine A and laetianolide A (Jullian et al. 2005). Preliminary phytochemical studies were performed but did not lead to a clear conclusion concerning the pure compounds responsible for the bioactivity of the extract it would thus be interesting to pursue the evaluation of the larvicidal activity of the pure compounds, and correlate L. procera bark extracts chemical profiles and larvicidal activity for example through a metabolomic approach.

M. oblongata extracts were not cytotoxic against KB and MCR5 human cell lines at 10 $\mu \mathrm{g} / \mathrm{mL}$, and exhibited noticeable toxicity against $C$. riparius whereas it did not have any activity against $D$. magna at $75 \mu \mathrm{g} / \mathrm{mL}$, as presented in a previously published article (Touré et al. 2017). This article also reported the isolation in $M$. oblongata extract of two new sesquiterpene alkaloids with a $\beta$-dihydroagrofuran skeleton and exhibiting significant activity against Paea strain Ae. aegypti larvae. Whereas published elsewhere, this work was 
performed by our team in the context of the same project, as bioguided fractionation of active extracts is indeed a key step to progress towards the development of novel botanical insecticides (Isman and Grieneisen, 2014; Pavela 2015; Pavela et al. 2019).

During the screening, Piper hispidum Sw. (Piperaceae) leaves ethyl acetate extract was also identified as active, with LC $_{50}$ values of 70.5 (CI95\% 60.4-81.6) and 54.7 (CI95\% 45.9-64.0) $\mu \mathrm{g} / \mathrm{mL}$ at 24 and $48 \mathrm{~h}$ against the laboratory strain Paea. However, due to the vast amount of existing literature on insecticidal Piperaceae and compounds isolated from Piper species such as piperine or dillapiole, ${ }^{42-44}$ we did not investigate further the chemical composition of this extract (Dorla et al. 2017; Lija-Escaline and al. 2015; Marques and Kaplan 2015). Moreover, if the potential development of a novel botanical insecticide is logically based on its biological activity and its selectivity, other criteria such as the availability of the resource are also fundamental when it comes to valorization (Borges et al. 2019; Pavela et al., 2019). We therefore chose to concentrate on $S$. rubra extract, the most active extract but also the $4^{\text {th }}$ species exploited in the forest industry in French Guiana, leading to wood wastes that could represent a source of valuable material and undisclosed as larvicidal product before the work of our team.

Sextonia rubra (Mez) Van der Werff (Lauraceae) wood and bark extracts were actually shown to possess excellent larvicidal activities in the context of this study. $S$. rubra is a neotropical shade-tolerant rainforest tree species native to South America, and one of the most commercially exploited wood for construction in French Guiana owing to its excellent natural durability. Two compounds rubrynolide and rubrenolide were first isolated from its stem wood in the early ' 70 s, and recently characterized in situ and identified in bark extracts, and their antifungal and termiticidal activities have been described (Franca et al. 1972; Fu et al. 2018, 2019; Houël et al. 2017; Rodrigues et al. 2010, 2011). As part of the cited work was performed by member of our team, we were able, following the previously described protocols, to characterize the chemical composition of the larvicidal extract and confirm the 
presence of the two $\gamma$-lactones rubrenolide and rubrynolide. We also highlighted during this project the strong larvicidal activity of these two compounds against Ae. aegypti, with respective $\mathrm{LC}_{50}$ of $3.84 \pm 0.02$ and $0.60 \pm 0.02$ for rubrynolide and rubrenolide at $24 \mathrm{~h}$, and $2.11 \pm 0.04$ and $0.30 \pm 0.02 \mu \mathrm{g} / \mathrm{mL}$ at $48 \mathrm{~h}$, alongside with a measured value of $3.15 \pm 0.02$ $\mu \mathrm{g} / \mathrm{mL}$ for the crude wood extract at $24 \mathrm{~h}$ and $2.06 \pm 0.02 \mu \mathrm{g} / \mathrm{mL}$ at $48 \mathrm{~h}$ (Falkowski et al. 2016). Following a patent deposit concerning the bioactivity of the wood extract and its constituents, a further evaluation of the larvicidal activity and its mechanisms will be performed, alongside with the characterization of its ecotoxicity (Falkowski et al. $\mathrm{N}^{\circ}$ WO2016046489 A1). Cytotoxicity of S. rubra was not evaluated in this study on KB and MRC5 cells, however it was demonstrated before that the two major compounds of wood and bark extracts, rubrenolide and rubrynolide, displayed low cytotoxicities on NIH-3T3 mammalian fibroblasts cells with $\mathrm{IC}_{50}$ values $>100 \mu \mathrm{g} / \mathrm{mL}$ in each case (Rodrigues et al. 2010). Complementary results have also been published, which highlighted notable toxicity for rubrenolide against several human cancer cell lines (Tofoli et al. 2016). This point will thus be further evaluated in the context of an ongoing project which aims at deepening the above-described results regarding the crude extract and isolated compounds and progressing towards the development of a marketable product.

\subsection{Multivariate analysis}

A generalized linear model (GLM) regression identified that solvents, organs, family and location are significantly associated to larvicidal potential of the extracts, while light, resources and vegetation type don't (Table 4). A second model was run using only those first four factors and a Tukey HSD test was computed on this second model. The significantly different comparisons are listed in Table 5 and full data are available in Table S2.

\footnotetext{
Variable Degree of freedom Sum of square $\quad$ Mean of square F-value $\quad$ P-value
} 


\begin{tabular}{lccccc}
\hline Solvent & 3 & 30.79 & 10.264 & 13.943 & $1.19 \mathrm{e}-08$ \\
Botanical family & 35 & 46.97 & 1.342 & 1.823 & 0.00367 \\
Location & 8 & 62.24 & 7.781 & 10.569 & $1.88 \mathrm{e}-13$ \\
Light & 2 & 1.32 & 0.658 & 0.894 & 0.40986 \\
Ressource & 2 & 0.26 & 0.129 & 0.175 & 0.83941 \\
Vegetation type & 3 & 3.48 & 1.162 & 1.578 & 0.19420 \\
Plant organs & 9 & 19.57 & 2.174 & 2.953 & 0.00209 \\
\hline Residuals & 389 & & 286.37 & & \\
\hline
\end{tabular}

Table 4 Anova analysis on quasi-Poisson generalized linear model (GLM) results

\begin{tabular}{|c|c|c|c|c|}
\hline & \multicolumn{2}{|c|}{$\mathrm{Cl} 95 \%$} & \multirow[b]{2}{*}{ Upper } & \multirow[b]{2}{*}{ P-value } \\
\hline & Differences & Lower & & \\
\hline \multicolumn{5}{|l|}{ Solvent $^{a}$} \\
\hline W / PE & -0.707 & -1.046 & -0.368 & $<0.001$ \\
\hline $\mathrm{PE} / \mathrm{M}$ & 0.584 & 0.283 & 0.885 & $<0.001$ \\
\hline W / EA & -0.479 & -0.788 & -0.171 & $<0.001$ \\
\hline $\mathrm{M} / \mathrm{EA}$ & -0.356 & -0.622 & -0.091 & 0.003 \\
\hline \multicolumn{5}{|l|}{ Organs } \\
\hline Inflorescence / Aerial parts & 1334 & 0.229 & 2.438 & 0.006 \\
\hline Stems / Inflorescence & -1.234 & -2.301 & -0.166 & 0.01 \\
\hline Leaves / Inflorescence & 1.201 & -2.259 & -0.142 & 0.013 \\
\hline Fruits / Aerial parts & 1.171 & 0.067 & 2.276 & 0.028 \\
\hline Stems / Fruits & -1.072 & -2.139 & -0.004 & 0.048 \\
\hline \multicolumn{5}{|l|}{ Family } \\
\hline Lauraceae / Annonaceae & 1.704 & 0.222 & 3.187 & 0.006 \\
\hline Lauraceae / Bignoniaceae & 1.82 & 0.021 & 3.62 & 0.043 \\
\hline Lauraceae / Costaceae & 1.701 & 0.091 & 3.31 & 0.023 \\
\hline Lauraceae / Dilleniaceae & 2.411 & 0.261 & 4.561 & 0.009 \\
\hline Lauraceae / Euphorbiaceae & 1.8 & 0.35 & 3.25 & 0.001 \\
\hline Lauraceae / Fabaceae & 1.697 & 0.301 & 3.093 & 0.002 \\
\hline Loranthaceae / Lauraceae & -1.949 & -3.802 & -0.096 & 0.025 \\
\hline Malpighiaceae / Lauraceae & -1.979 & -3.513 & -0.444 & 0.001 \\
\hline Malvaceae / Lauraceae & -2.05 & -3.973 & -0.126 & 0.02 \\
\hline Meliaceae / Lauraceae & -1.889 & -3.645 & -0.133 & 0.018 \\
\hline Sapindaceae / Lauraceae & -1.61 & -3.118 & -0.101 & 0.02 \\
\hline Sapotaceae / Lauraceae & -1.93 & -3.729 & -0.131 & 0.018 \\
\hline
\end{tabular}




\begin{tabular}{lcccc}
\hline Siparunaceae / Lauraceae & -1.91 & -3.709 & -0.111 & 0.022 \\
Solanaceae / Lauraceae & -1.543 & -3.064 & -0.023 & 0.041 \\
\hline Location & & & & \\
Si-Mo & -2.353 & -3.328 & -1.377 & $<0.001$ \\
Rg-Mo & -2.454 & -3.48 & -1.428 & $<0.001$ \\
Mo-Mc & 2.414 & 1.415 & 3.413 & $<0.001$ \\
Mo-Ma & 2.391 & 1.389 & 3.393 & $<0.001$ \\
Mo-Ko & 2.383 & 1.393 & 3.373 & $<0.001$ \\
Mt-Mo & -2.581 & -3.924 & -1.238 & $<0.001$ \\
Rm-Mo & -3.126 & -5.251 & -1.002 & $<0.001$ \\
Ro-Mo & -3.898 & -6.748 & -1.048 & 0.001 \\
\hline
\end{tabular}

${ }^{a} \mathrm{~W}$ : water. PE: petroleum ether. M: methanol. EA: ethyl acetate

${ }^{\text {b }}$ Si: Sinnamary. Mo: Montsinéry-Tonnegrande. Rg: Régina. Mc: Macouria. Ma: Mana. Ko:

Kourou. Mt: Matoury. Rm: Rémire-Montjoly. Ro: Roura

Table 5 Tukey HSD significant pairwise differences between variables

Analysis revealed that mortalities observed for methanol and water extracts were significantly lower than those obtained for petroleum ether and ethyl acetate extracts. Similar results had been previously reported in structure-activity studies (Carreno Otero et al., 2014; Santos et al. 2010). It can be assumed that more polar compounds are less prone to penetrate larvae cuticles, whereas lipophilic compounds have higher affinity for cell membranes and insect cuticles (Chen et al. 2014; Santos et al. 2010). In a study comparing the larvicidal, morphological and behavorial response of Ae. aegypti to various extracts of Argemone mexicana L. (Papaveraceae), apolar extracts were shown to be the most efficient, inducing modification of larvae cuticles (Warikoo and Kumar, 2013). Our dataset reinforces the interest of lipophilic extracts and compounds as larvicidal products.

Among plant organs (bark, wood, stem, leaves, roots, aerial parts, whole plant, inflorescence and fruits), mortalities induced by the inflorescence extracts were significantly higher than for 
aerial parts, stems and leaves. Fruits also induced higher mortality than aerial parts and stems. Inflorescences were only collected from Costus species (C. erythrothyrsus, C. spiralis var. villosus, $C$. cf. spiralis) and among the 7 tested extracts, 2 exhibited strong larvicidal potential (97-100\% mortality) whereas the other 5 were inactive $(0-2 \%$ mortality). Fruits were collected from 3 species (Matayba arborescens and Cupania scrobitulata, Sapindaceae, Tetracera asperula, Dilleniaceae) and alongside the leaves of Maytenus sp. (Celastraceae). Over 9 tested extracts 4 were moderately active (32 to 64\% larval mortality) whereas the remaining 5 were inactive (0-1\% mortality), including the 2 Tetracera extracts (Table S1 Supporting Information). As discussed above, particular cases (damaged Costus inflorescence) and chemotaxonomy (Celastraceae and Sapindaceae being well-known insecticidal plants) may explain part of these results. However, the fact that reproductive organs (fruits and inflorescences) exhibit significantly higher larvicidal effect than nonreproductive organs (aerial parts, stems and leaves) is a point of interest in the light of plant species defense. In their work, McCall and Fordyce could not conclude on a possible more intense defense allocation in flowers compared to leaves (McCall and Fordyce 2010). This result possibly originated either from the fact that flowers are not so more valuable than leaves, or simply from a lack of power of the analysis due to a reduced dataset. A recent work for its part demonstrated that wild tobacco flowers accumulate large amounts of defensive compounds, which expression is specifically regulated by jasmonate phytohormones signaling (Li et al. 2017). Moreover, reproductive tissues (including anthers, nectary, ovary, style and stigma) where shown to exhibit higher relative levels of defenserelated compounds than vegetative tissues (leaf, root, stem and seed) in a metabolic specialization study of the Nicotiana attenuata Torr. ex S. Watson (Solanaceae) model species ( Li et al. 2016). Also, the comparison of the natural variation in glucosinolate between vegetative and reproductive tissues in Boechera stricta (Graham) Al-Shehbaz (Brassicaceae) revealed much higher concentrations of these defense compounds in fruits compared to leaves (Keith and Mitchell-Olds, 2017). In our case, insecticide activity was detected in inflorescence and fruits extracts of Costus and Cupania species while leaves and 
stem extracts were all inactive. For Maytenus and Matayba extracts, the observation of the dataset does not lead to obvious conclusions concerning defense allocation. In our study, roots or barks were not highlighted as organ leading to higher proportion of larvicidal extracts. However, these tissues may be of interest in a wider dataset. For example, higher levels of glucosinolate were detected in roots than in shoots of several species, and a higher chemical diversity of both monoterpenes and sesquiterpenes were released by barks compared to leaves immediately after mechanical damage for 178 individual trees belonging to 55 angiosperm species in French Guiana (Courtois et al. 2012; Tsunoda et al. 2017). This later finding was attributed to a larger investment in chemical defenses in the bark. Overall, our data together with the above cited literature suggest that plant organs are differently protected against pests. More active insecticides are found in reproductive organs, and recent herbivory/damage can significantly increase the probability to obtain active extracts. The choice of lipophilic extraction solvent is also critical.

Results concerning families and location are difficult to interpret due to the small size of the dataset. Although expected according to other works, light, resource availability and vegetation type did not significantly affect insecticide potential (Endara and Coley, 2011; Fine et al. 2006, 2013; Smilanich et al. 2016). One reason may be that the objective of developing botanical insecticides prompted us to investigate specifically plant qualitative defense compounds (small weight highly active molecules). These do not represent the totality of plant defensive arsenal. Quantitative defense compounds, such as tannins, are not accessible by these techniques (De Almeida et al. 2005).

\section{Conclusion}

The above discussed examples distinctly point out the fact, highlighted by Isman and Grieneisen (2014), that collecting a single sample from a single specimen does not allow to conclude on the interest of a given species as a new source of insecticide, and that chemical characterization of the studied extracts can clearly add value to this type of study. Moreover, 
we also exemplified that plant defensive chemistry mechanisms are crucial while trying to discover insecticidal products, even if the search for toxic compounds only encompasses a small facet of this highly complex machinery. Multivariate analysis allowed us to identify lipophilic solvents as the most interesting to yield insecticide extracts, and highlighted the fact that extending screening to various plant tissues, in particular reproductive organs, could lead to new promising larvicidal compounds. Analyzing existing dataset and conducting screening studies inspired by the functional role of secondary metabolites in nature, in the light of the chemistry of defense and with the understanding of the mechanisms driving resource allocations as proposed by Berenbaum or Miresmailli and Isman, could therefore help renewing the old-fashioned field of insecticidal natural products (Berenbaum 1995; Miresmailli and Isman 2014).

\section{Supporting information}

Supporting information may be found in the online version of this article.

\section{Conflict of interest}

On behalf of all authors, the corresponding authors state that there is no conflict of interest.

\section{Declaration of interests}

$\bigotimes$ The authors declare that they have no known competing financial interests or personal relationships that could have appeared to influence the work reported in this paper.

\section{Acknowledgment}

This work is part of the INSECTICIDES project funded by Europe (European Regional Development Fund Operational Programme, PRESAGE №31220), French Guiana Regional Council and the Air Liquide Foundation. This research was part of the Laboratory of Excellence "Centre de la Biodiversité Amazonienne" [Labex CEBA (CEBA, ref ANR-10LABX-25-01)] and of the STRonGer consortium (Institut Pasteur de la Guyane). This work 
benefited from an "Investissement d'Avenir" grant managed by Agence Nationale de la Recherche (Infrastructure Nationale en Biologie Santé "ANAEE-France" ANR-11-INBS-0001) through the use of the U3E INRA1036 PEARL platform.

The authors thank Bruno Clair (CNRS/UMR EcoFoG) and collaborators for providing Bagassa guianensis Aubl. (Moraceae) bark andexpress their gratitude to Bruno Hérault (CIRAD/UMR EcoFoG) for helping in statistical analysis. The authors also thank Vincent Jacquet for illustrating this article through the design of the graphical abstract.

\section{References}

Abílio AP, Abudasse G, Kampango A, Candrinho B, Sitoi S, Luciano J, Tembisse D, Sibindy S, de Almeida APG, Garcia GA, David MR, Maciel-de-Freitas R, Gudo ES (2018) Distribution and breeding sites of Aedes aegypti and Aedes albopictus in 32 urban/peri-urban districts of Mozambique: implication for assessing the risk of arbovirus outbreaks. PLoS Negl Trop Dis. 12:e0006692, https://doi.org/10.1371/journal.pntd.0006692.

Abbott W (1925) A method of computing the effectiveness of an insecticide. J Econ Entomol 18:265-267, https://doi.org/10,1093/jee/18.2.265a

Agrawal AA, Weber MG (2015) On the study of plant defence and herbivory using comparative approaches: how important are secondary plant compounds. Ecol Lett 18:985991, https://doi.org/10.1111/ele.12482

Alvarenga N, Ferro EA (2005) Bioactive triterpenes and related compounds from Celastraceae. In: Atta-ur-Rahman (ed) Studies in natural products chemistry vol. 30 Bioactive natural products (Part K), Elsevier, pp.635-702

Becerra JX (2007) The impact of herbivore-plant coevolution on plant community structure. Proc Natl Acad Sci USA 104:7483-7488, https://doi.org/10.1073_pnas.0608253104

Benelli G (2015) Research in mosquito control: current challenges for a brighter future. Parasitol Res 114:2801-2805, https://doi.org/10.1007/s00436-015-4586-9 
Benelli G, Mehlhorn H (2016) Declining malaria, rising of dengue and Zika virus: insights for mosquito vector control. Parasitol Res 115:1747-1754, https://doi.org/10.1007/s00436-016$4971-z$

Berenbaum MR (1995) The chemistry of defense: theory and practice. Proc Natl Acad Sci USA 92:2-8, https://doi.org/10.1073/pnas.92.1.2

Borges JCM, Haddi K, Oliveira EE, Andrade BS, Nascimento VL, Melo TS, Didonet J, Carvalho JCT, Cangussu AS, Soares IM, Ascencio SD, Raposo NRB, Aguiar RWS (2019) Mosquiticidal and repellent potential of formulations containing wood residue extracts of a Neotropical plant, Tabebuia heptaphylla. Ind Crops Prod 129:424-433, https://doi.org/10.1016/j.indcrop.2018.12.022

Boulogne I, Petit P, Ozier-Lafontaine H, Desfontaines L, Loranger-Merciris G (2012) Insecticidal and antifungal chemicals produced by plants: a review. Environ Chem Lett 10:325-347, https://doi.org/10.1007/s10311-012-0359-1

Carreño Otero AL, Vargas Méndez LY, Duque LJE, Kouznetsov VV (2014) Design, synthesis, acetylcholinesterase inhibition and larvicidal activity of girgensohnine analogs on Aedes aegypti, vector of dengue fever. Eur $J$ Med Chem 78:392-400, https://doi.org/10.1016/j.ejmech.2014.03.067

Carvalho FD, Moreira LA (2017) Why is Aedes aegypti Linnaeus so successful as a species? Neotrop Entomol 46:243-255, https://doi.org/10.1007/s13744-017-0520-4

Chen X, Mukwaya E, Wong M-S and Zhang Y (2014) A systematic review on biological activities of prenylated flavonoids. Pharm Biol 52:655-660, https://doi.org/10.3109/13880209.2013.853809

Coley PD, Bryant JP, Chapin FS (1985) Resource availability and plant antiherbivore defense. Science 230:895-899, https://doi.org/10.1126/science.230.4728.895

Cos P, Vlietlinck AJ, Vanden Berghe D, Maes L (2006) Anti-infective potential of natural products: How to develop a stronger in vitro 'proof-of-concept'. J Ethnopharmacol 106:290302, https://doi.org/10.1016/j.jep.2006.04.003 
Courtois EA, Baraloto C, Paine CET, Petronelli P, Blandinieres P-A, Stien D, Houël E, Bessiere J-M, Chave J (2012) Differences in volatile terpene composition between the bark and leaves of tropical tree species. Phytochemistry 82:81-88, https://doi.org/10.1016/j.phytochem.2012.07.003

Cuca-Suárez LEC, Mendoza-Meza DL, Álvarez-Caballero J, Macías-Villamizar V, CoyBarrera ED (2012) Acaricide activity of Lauraceae extracts against domiciliary mites Dermatophagoides farinae and Blomia tropicalis. Rev Cubana Plant Med 17:308-319, https://doi.org/

Da Silva TBC, Alves VL, Mendonça LVH, Conserva LM, da Rocha EMM, Andrade EHA, Lemos RPL (2004) Chemical constituents and preliminary antimalarial activity of Humiria balsamifera. Pharm Biol 42:94-97, https://doi.org/10.1 OX011 3880200490510702

De Almeida CFCBR, De Lima E Silva TC, De Amorim ELC, Maia MBDS, De Albuquerque UP (2005) Life strategy and chemical composition as predictors of the selection of medicinal plants from the caatinga (Northeast Brazil). J Arid Environ 62:127-142, https://doi.org/10.1016/j.jaridenv.2004.09.020

Deepa MA, Narmatha Bai V (2010) Bioinsecticidal compounds of Celastraceae - the Spindle Tree family. Int J Bot 6:220-227, https://doi.org/10.3923/ijb.2010.220.227

Dias CN, Moraes DFC (2014) Essential oils and their compounds as Aedes aegypti L. (Diptera: Culicidae) larvicides: review. Parasitol Res 113:565-592, https://doi.org/10.1007/s00436-013-3687-6 Diaz M and Rossini C (2012) Bioactive natural products from Sapindaceae deterrent and toxic metabolites against insects. In: Perveen F (ed) Insecticides - Pest Engineering, InTech, pp. $287-308$

Domingues SJS, de Souza TF, Soares AMS, Jacinto T, Machado OLT (2007) Activation of phospholipase PLA2 actvity in Ricinus communis leaves in response to mechanical wounding. Braz J Plant Physiol 19:35-42, https://doi.org/10.1590/S167704202007000100004 
Dorla E, Gauvin-Bialecki A, Deuscher Z, Allibert A, Grondin I, Deguine J-P, Laurent P (2017) Insecticidal activity of the leaf essential oil of Peperomia borbonensis Miq. (Piperaceae) and its major components against the Melon Fly Bactrocera cucurbitae (Diptera: Tephritidae). Chem Biodiv 14:e1600493, https://doi.org/10.1002/cbdv.201600493

Dusfour I, Thalmensy V, Gaborit P, Issaky J, Carinci R, Girod R (2011) Multiple insecticide resistance in Aedes aegypti (Diptera: Culicidae) populations compromises the effectiveness of dengue vector control in French Guiana. Mem Inst Oswaldo Cruz 106: 346-352

Ehrlich PR, Raven PH (1964) Butterflies and plants: a study in coevolution. Evolution 18:586-608, https://doi.org/10.1590/s0074-02762011000300015

Endara MJ,Coley PD (2011) The resource availability hypothesis revisited: a meta-analysis. Funct Ecol 25:389-398, doi : 10.1111/j.1365-2435.2010.01803.x

Falkowski M, Rodrigues A, Eparvier V, Dusfour I, Houël E, Stien D (2014) Propriétés insecticides d'un extrait de Sextonia rubra, et de ses constituants, Patent NWO2016046489 A1

Falkowski M, Jahn-Oyac O, Ferrero E, Issaly J, Eparvier V, Rodrigues AMS, Stien D, Houël E and Dusfour I (2016) Assessment of a simple compound-saving method to study insecticidal activity of natural extracts and pure compounds against mosquito larvae. J Am Mosq Control Assoc, 32:337-340, https://doi.org/10.2987/16-6613.1

Fauci AS, Morens DM (2016) Zika Virus in the Americas - Yet Another Arbovirus Threat. N Engl J Med 374:601-604, https://doi.org/10.1056/NEJMp1600297

Faucon F, Dusfour I, Gaude T, Navratil V, Boyer F, Chandre F, Sirisopa P, Thanispong K, Juntarajumnong W, Poupardin R, Chareonviriyaphap T, Girod R, Corbel V, Reynaud S, David JP (2015) Identifying genomic changes associated with insecticide resistance in the dengue mosquito Aedes aegypti by deep targeted sequencing. Genome Res 25:1347-1359, https://doi.org/10.1101/gr.189225.115 
Feeny PP (1976) Plant apparency and chemical defence. In: Wallace J, Mansell R (ed) Biochemical interactions between plants and insects. Recent advances in phytochemistry. Academic Press, New York, NY, USA, pp. 1-40

Fine PA, Metz MR, Lokvam J, Mesones I, Zuniga JMA, Lamarre GPA, Pilco MV, Baraloto C (2013) Insect herbivores, chemical innovation, and the evolution of habitat specialization in Amazonian trees. Ecology 94:1764-1775, https://doi.org/10.1890/12-1920.1

Fine PV, Miller ZJ, Mesones I, Irazuzta S, Appel HM, Stevens MH, Sääksjärvi I, Schultz JC, Coley PD (2006) The growth-defense trade-off and habitat specialization by plants in Amazonian forests. Ecology 87:S150-62

Fraenkel G (1959) The raison d'être of secondary plant substances. Science 129:14661470, https://doi.org/10.1126/science.129.3361.1466

Franca NC, Gottlieb OR, Coxon DT, Ollis WD (1972) Constitutions of rubrenolide and rubrynolide: an alkene-alkyne pair from Nectandra rubra. J Chem Soc, Chem Comm 514515, https://doi.org/10.1039/C39720000514

Fu T, Touboul D, Della-Negra S, Houël E, Amusant N, Duplais C, Fisher GL, Brunelle A (2018) Tandem MS imaging and in situ identification of bioactive wood metabolites in Amazonian tree species Sextonia rubra. Anal Chem 90:7535-7543, https://doi.org/10.1021/acs.analchem.8b01157

Fu T, Houël E, Amusant N, Touboul D, Genta-Jouve G, Della-Negra S, Fisher GL, Brunelle A, Duplais C (2019) Biosynthetic investigation of $\gamma$-lactones in Sextonia rubra wood using in situ TOF-SIMS MS/MS imaging to localize and characterize biosynthetic intermediates. Sci Rep 9:1928, https://doi.org/10.1038/s41598-018-37577-5

George DR, Finn RD, Graham KM, Sparagano OAE (2014) Present and future potential of plant-derived products to control arthropods of veterinary and medical significance. Parasit Vectors 7:28-39, https://doi.org/10.1186/1756-3305-7-28

Gerwick BC, Sparks TC (2014) Natural products for pest control: an analysis of their role, value and future. Pest Manag Sci 70:1169-1185, https://doi.org/10.1002/ps.3744 
Harada K, Suomalainen M, Uchida H, Masui H, Ohmura K, Kiviranta J, Niku-Paavola ML, Ikemoto T (2000) Insecticidal compounds against mosquito larvae from Oscillatoria agardhii strain 27. Environ Toxicol 15:114-119, https://doi.org/10.1002/(SICI)15227278(2000) 15:2<114::AID-TOX7>3.0

Higgs S, Vanlandingham D (2015) Chikungunya virus and its mosquito vectors. Vector Borne Zoonotic Dis 15:231-240, https://doi.org/10.1089/vbz.2014.1745

Houël E, Rodrigues AMS, Nicolini E, Ngwete O, Duplais C, Stien D, Amusant N (2017) Natural durability of Sextonia rubra, an Amazonian tree species: description and origin. IRG/WP 17-10887, Proceedings IRG Annual Meeting; ISSN 2000-8953

Isman MB (2006) Botanical insecticides, deterrents and repellents in modern agriculture and an increasingly regulated world. Annu Rev Entomol 51:45-66, https://doi.org/10.1146/annurev.ento.51.110104.151146

Isman MB (2015) A renaissance for botanical insecticides? Pest Manag Sci 71:1587-1590 Isman MB, Grieneisen ML (2014) Botanical insecticide research: many publications, limited useful data. Trends Plant Sci 19:140-145, https://doi.org/10.1002/ps.4088

Jeevani Osadee Wijekoon MM, Karimand AA, Bhat R (2011) Evaluation of nutritional quality of torch ginger (Etlingera elatior Jack.) inflorescence. Int Food Res J 18:1415-1420

Jullian V, Bonduelle C, Valentin A, Acebey L, Duigou A-G, Prévost M-F, Sauvain M (2005) New clerodane diterpenoids from Laetia procera (Poepp.) Eichler (Flacourtiaceae), with antiplasmodial and antileishmanial activities. Bioorg Med Chem Lett 15:5065-5070, https://doi.org/10.1016/j.bmcl.2005.07.090

Keith RA, Mitchell-Odds T (2017) Testing the optimal defense hypothesis in nature: variation for glucosinolate profiles within plants. PloS One 12:e0180971, https://doi.org/10.5061/dryad.b2t42.

Lamarre GPA, Baraloto C, Fortunel C, Davila N, Mesones I, Rios JG, Rios M, Valderrama E, Pilco MV, Fine PVA (2012) Herbivory, growth rates, and habitat specialization in tropical tree lineages : implications for Amazonian beta-diversity. Ecology 93:5195-5210, https://doi.org/10.1890/11-0397.1 
L'Azou M, Taurel A-F, Flamand C, Quénel P (2014) Recent epidemiological trends of dengue in the French territories of the Americas (2000-2012): a systematic literature review. PLoS Negl Trop Diseases 8:e3235, https://doi.org/10.1371/journal.pntd.0003235

Li D, Heiling S, Baldwin IT, Gaquerel E (2016) Illuminating a plant's tissue-specific metabolic diversity using computational metabolomics and information theory. Proc Natl Acad Sci USA E7610-E7618, https://doi.org/10.1073/pnas.1610218113

Li R, Wang M, Schuman MC, Weinhold A, Schäfer M, Jimenez-Aleman GH, Barthel A, Baldwin IT (2017) Flower-specific jasmonate signaling regulates constitutive floral defense in wild tobacco. Proc Natl Acad Sci USA E7205-E7214, https://doi.org/10.1073/pnas.1703463114

Lija-Escaline J, Senthil-Nathan S, Thanigaivel A, Pradeepa V, Vasantha-Srinivasan P, Ponsankar A, Edwin ES, Selin-Rani S, Abdel-Megeed A (2015) Physiological and biochemical effects of botanical extract from Piper nigrum Linn (Piperaceae) against the dengue vector. Parasitol Res 114:4239-4249, https://doi.org/10.1007/s00436-015-4662-1

Lima E, Paiva M, Araújo A, Da Silva E, Da Silva U, Oliveira L, Santana A, Barbosa C, Neto C, Goulart M, Wilding C, Ayres C and Santos M (2011) Insecticide resistance in Aedes aegypti populations from Ceará, Brazil. Parasite Vector 4:5, https://doi.org/10.1186/1756$3305-4-5$

Macêdo ME, Consoli RAGB, Grandi TSM, dos Anjos AMG, de Oliveira AB, Mendes NM, Queiroz RO, Zani CL (1997) Screening of Asteraceae (Compositae) plant extracts for larvicidal activity against Aedes fluviatilis (Diptera: Culicidaea). Mem Inst Oswaldo Cruz 92:565-570, https://doi.org/10.1590/s0074-02761997000400024

Marques AM, Kaplan MAC (2015) Active metabolites of the genus Piper against Aedes aegypti: natural alternative sources for dengue vector control. Univ Sci 20:61-82, https://doi.org/10.11144/Javeriana.SC20-1.amgp

McCall AC, Fordyce JA (2010) Can optimal defence theory be used to predict the distribution of plant chemical defences? J Ecol 98:985-992, https://doi.org/10.1111/j.13652745.2010.01693.x 
McKey D (1974) Adaptive patterns in alkaloid physiology. Am Nat 108:305-320.

Miresmailli S, Isman MB (2015) Botanical insecticides inspired by plant-herbivore chemical interactions. Trends Plant Sci 19:29-35, https://doi.org/10.1086/282909

Moyes CL, Vontas J, Martins AJ, Ng LC, Koou SY, Dusfour I, Raghavendra K, Pinto J, Corbel V, David J-P, Weetman D (2017) Contemporary status of insecticide resistance in the major Aedes vectors of arboviruses infecting humans. PLoS Negl Trop Dis 11:e0005625, doi : 10.1371/journal.pntd.0005625

Nirma C, Rodrigues AMS, Basset C, Chevolot L, Girod R, Moretti C, Stien D, Dusfour I, Eparvier V (2012) Larvicidal activity of isoflavonoids from Muellera frutescens extracts against Aedes aegypti. Nat Prod Comm 7:1-4, https://doi.org/10.1177/1934578X1200701016 Oliveira PV, Ferreira JC, Moura FS, Lima GS, de Oliveira FM, Oliveira PES, Conserva LM, Giulietti AM, Lemos RPL (2010) Larvicidal activity of 94 extracts from ten plant species of northeastern of Brazil against Aedes aegypti L. (Diptera: Culicidae). Parasitol Res 107:403407, https://doi.org/10.1007/s00436-010-1880-4

Pavela R (2015) Essential oils for the development of eco-friendly mosquito larvicides: a review. Ind Crops Prod 76:174-187, http://dx.doi.org/10.1016/j.indcrop.2015.06.050

Pavela R, Maggi F, lannarelli R, Benelli G (2019) Plant extracts for developing mosquito larvicides: From laboratory to the field, with insights on the modes of acton. Acta Trop 193: 236-271, https://doi.org/10.1016/j.actatropica.2019.01.019

Pipithsangchan S, Morallo-Rejesus B (2005) Insecticidal activity of diosgenin isolated from three species of grape ginger (Costus spp.) on the diamondback moth, Plutella xylostella (L.). Philipp Agric Sci 88:317-327

Rahuman AA, Venkatesan P, Gopalakrishnan G (2008) Mosquito larvicidal activity of oleic and linoleic acids isolated from Citrullus colocynthis (Linn.) Schrad. Parasitol Res 103:13831390, https://doi.org/10.1007/s00436-008-1146-6

Ramsewak RS, Nair MG, Murugesan S, Mattson WJ, Zasada J (2001) Insecticidal fatty acids and triglycerides from Dirca palustris. J Agric Food Chem 49:5852-5856, https://doi.org/10.1021/jf010806y 
Rhoades D, Cates RG (1976) Toward a general theory of plant antiherbivore chemistry. In: Wallace J, Mansell R (ed) Biochemical interactions between plants and insects. Recent advances in phytochemistry. Academic Press, New York, NY, USA, pp. 155-204

Richards LA, Dyer LA, Forister ML, Smilanich AM, Dodson CD, Leonard MD, Jeffrey CS (2015). Phytochemical diversity drives plant-insect community diversity. Proc Natl Acad Sci USA 112:10973-10978, https://doi.org/10.1073/pnas.1504977112

Rodrigues AMS, Theodoro PNET, Eparvier V, Basset C, Silva MRR, Beauchêne J, Espindola LS, Stien D (2010) Search for antifungal compounds from the wood of durable tropical trees. J Nat Prod 73:1706-1707, https://doi.org/10.1021/np1001412

Rodrigues AMS, Amusant N, Beauchêne J, Eparvier V Leménager N, Baudassé C, Espíndola LS, Stien D (2011) The termiticidal activity of Sextonia rubra (Mez) van der Werff (Lauraceae) extract and its active constituent rubrynolide. Pest Manag Sci 67:1420-1423, https://doi.org/10.1002/ps.2167

Rojas CM, Senthil-Kumar M, Tzin V, Mysore KS (2014) Regulation of primary plant metabolism during plant-pathogen interactions and its contribution to plant defense. Front Plant Sci 5:17, https://doi.org/10.3389/fpls.2014.00017

Ryu SB, Lee HY, Doelling JH, Palta JP (2005) Characterization of a cDNA encoding Arabidopsis secretory phospholipase A2- $\alpha$, an enzyme that generates bioactive lysophospholipids and free fatty acids. Biochim Biophys Acta BBA -Mol Cell Biol Lipids 1736:144-151, https://doi.org/10.1016/j.bbalip.2005.08.005

Sacchi R, Addeo F, Paolillo L (1997) ${ }^{1} \mathrm{H}$ and ${ }^{13} \mathrm{C}$ NMR of virgin olive oil. An overview. Magn Reson Chem 35:S133-S145, https://doi.org/10.1002/(SICI)1097458X(199712)35:13<S133::AID-OMR213>3.0.CO;2-K

Santos SRL, Silva VB, Melo MA, Barbosa JFF, Santos RLC, De Sousa DP, Cavalcanti SCH (2010) Toxic effects on and structure-toxicity relationships of phenylpropanoids, terpenes, and related compounds in Aedes aegypti larvae. Vector Borne Zoonotic Dis 10:1049-1054, https://doi.org/10.1089/vbz.2009.0158 
Santos GGA, Santos BA, Nascimento HEM and Tabarelli M (2012) Contrasting demographic structure of short- and long-lived pioneer tree species on Amazonian forest edges. Biotropica 44:771-778, https://doi.org/10.1111/j.1744-7429.2012.00882.x

Santos LMM, Nascimento JS, Santos MAG, Marriel NB, Bezerra-Silva PC, Rocha SKL, Silva AG, Correia MTS, Paiva PMG, Martins GF, Navarro DMAF, Silva MV, Napoleão TH (2017) Fatty acid-rich volatile oil from Syagrus coronata seeds has larvicidal and ovipositiondeterrent activities against Aedes aegypti. Physiol Mol Plant Pathol 100:35-40, https://doi.org/10.1016/j.pmpp.2017.05.008

Simmons CP, Farrar JJ, Chau NVV, Wills B (2012) Dengue. N Engl J Med 366:1423-1432, https://doi.org/ 10.1056/NEJMra1110265

Smilanich AM, Fincher RM, Dyer LA (2016) Does plan apparency matter? Thirty years of data provide limited support but reveal clear patterns of the effects of plant chemistry on herbivores. New Phytologist 210:1044-1057, https://doi.org/10.1111/nph.13875

Specht CD, Stevenson DW (2006) A new phylogeny-based generic classification of Costaceae (Zingiberales). Taxon 55:153-163, https://doi.org/10.1600/036364415X686404 Surendra Kumar M, Aswathy TN, Suhail CN, Astalakshmi N, Babu G (2014) Studies on Costus speciosus Koen alcoholic extract for larvicidal activity. Int J Pharmacogn Phytochem Res 5:328-329

Tsunoda T, Krosse S, Van Dam NM (2017) Root and shoot glucosinolate allocation patterns follow optimal defence allocation theory. J Ecol 105:1256-1266, https://doi.org/10.1111/13652745.12793

Tempête C, Werner G, Favre F, Roja A, Langlois N (1995) In vitro cytostatic activity of 9demethoxyporothramycin B. Eur J Med Chem 30:647-650, https://doi.org/10.1016/0223$5234(96) 88281-X$

Tófoli D, Martins LAV, Matos MFC, Garcez WS, Garcez FG (2016) Antiproliferative butyrolactones from Mezilaurus crassiramea. Planta Med Lett 3:e14-e16, https://doi.org/10.1055/s-0035-1568355 
Touré S, Nirma C, Falkowski M, Dusfour I, Boulogne I, Jahn-Oyac A, Coke M, Azam D, Girod R, Moriou C, Odonne G, Stien D, Houël E, Eparvier V (2017) Aedes aegypti larvicidal sesquiterpene alkaloids from Maytenus oblongata. J Nat Prod 80:384-390, https://doi.org/10.1021/acs.jnatprod.6b00850

Wang C, Lü L, Zhang A, Liu C (2013) Repellency of selected chemicals against the bed bug (Hemiptera: Cimicidae). J Econ Entomol 106:2522-2529, https://doi.org/10.1603/EC13155

Warikoo R, Kumar S (2013) Impact of Argemone mexicana extracts on the cidal, morphological, and behavioral response of dengue vector, Aedes aegypti L. (Diptera: Culicidae). Parasitol Res 112:3477-3484, https://doi.org/10.1007/s00436-013-3528-7

World Health Organization (2005) Guidelines for Laboratory and Field Testing of Mosquito Larvicides. http://apps.who.int/iris/bitstream/10665/69101/1/WHO_CDS_WHOPES_GCDPP _2005.13.pdf

Zhang A, Klun JA, Wang S, Carroll JF, Debboun M (2009) Isolongifolenone: a novel sesquiterpene repellent of ticks and mosquitoes. J Med Entomol 46:100-106, https://doi.org/10.1603/033.046.0113 


\section{Summary}

36 French Guiana biodiversity was explored for the search of novel larvicidal products against

37 both insecticide-susceptible and -resistant Aedes aegypti populations.

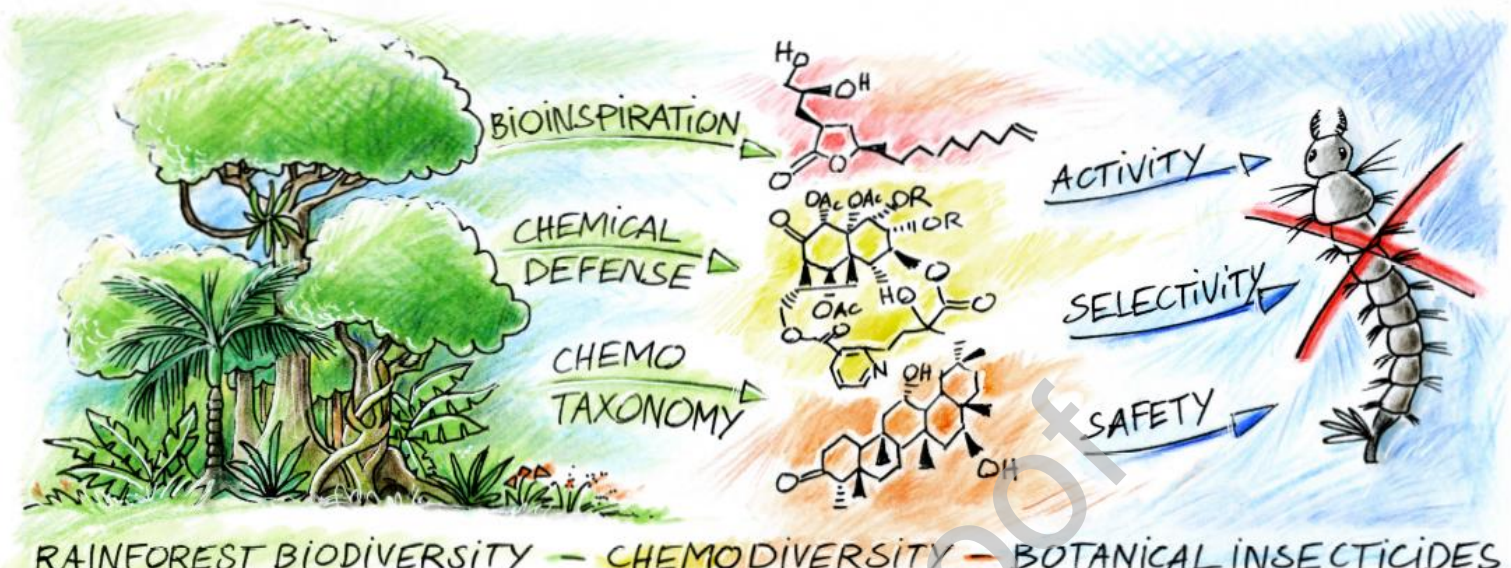

\section{Graphical abstract}

